\title{
THE EVOLUTION OF STATE SUPREME COURTS
}

\author{
Robert A. Kagan* \\ Bliss Cartwright** \\ Lawrence M. Friedman*** \\ Stanton Wheeler ${ }^{* * * *} \dagger$
}

The past century has seen a striking variation in the size of state supreme courts' caseloads-the number of appeals they hear and opinions they write. Some courts ${ }^{1}$ issued 500 opinions or more in a single year; others wrote fewer than 100. A single court's caseload sometimes doubled from one decade to the next and then declined again. This Article reports the findings of our research on how caseload size affected the structure and business of American state supreme courts from 1870 to 1970.2 These findings derive from a study of state supreme courts, as revealed by selected quantitative measures. We have asked: How many cases did these courts decide? And what kinds? What types of litigants did they serve? How did their work change over the years? How did it differ from state to state? What do the changes suggest about the direction of state supreme court development and about the causal links between social conditions and legal change?

\footnotetext{
* Associate Professor of Political Science, University of California, Berkeley. A.B. 1959, Harvard College; LL.B. 1962, Columbia University; Ph.D. 1974, Yale University.-Ed.

** Assistant Professor of Sociology and Law, University of Virginia. A.B. 1963, Oberlin College; M.A. 1965, University of Pittsburgh; Ph.D. 1970, Northwestern University.-Ed.

*** Marion Rice Kirkwood Professor of Law, Stanford University. B.A. 1948, J.D. 1951, M.LL. 1953, University of Chicago.-Ed.

**** Professor of Law and Sociology, Yale University. B.A. 1952, Pomona College; M.A. 1956, Ph.D. 1958, University of Washington.-Ed.

t Work on this Article was supported by National Science Foundation Grant No. GS-38413. The authors thank everyone who assisted and advised them in gathering and analyzing the data set forth in this Article, and add particular thanks to Professor John P. Hartigan (Statistics Department, Yale University), Mary Bertolet, Richard Coffin, Tom Fitzpatrick, Edward Grossman, Peter Harris, Al John, Kent Khtikian, James Meeker, Donald Percival, Ronnie Ratner, Jay Warren, and especially Diana Polise. Thomas Marvell of the National Center for State Courts gave us important and constructive criticism.

1. Unless otherwise indicated, "court" and "supreme court" refer to state supreme courts. "Appellate court" refers specifically to an intermediate appellate court between a state's trial and highest courts.

2. Other findings from this research project have been published in Kagan, Cartwright, Friedman, \& Wheeler, The Business of State Supreme Courts, 1870-1970, 30 STAN. L. REv. 121 (1977), and Note, Courting Reversal: The Supervisory Role of State Supreme Courts, 87 YALE L.J. 1191 (1978).
} 
By arranging and rearranging our information on fluctuating supreme court caseloads, and comparing it with other quantitative measures of court performance, such as dissent rates, length of opinions, and types of issues decided, we discerned a rough pattern of evolution: as a state's population grew, its supreme court's caseload (measured by published opinions) usually grew along with it, sometimes quite dramatically. The increase in caseload naturally evoked efforts to reorganize the judiciary system to relieve the pressure on the court. Eventually, states with heavy caseloads introduced structural reforms, principally intermediate appellate courts, and increased the supreme court's control over its docket. These changes, moreover, seemed to affect the supreme courts' legal role, for they coincided with changes in the type of case heard, the way courts made decisions, and the results of cases.

The relationships are neither perfect nor exact. The supreme courts of the different states developed in the same direction. But they have not moved in lockstep through fixed stages of development. Court reform, always a complex process, was uniquely shaped in every state by intensely local political battles. Still, our quantitative measures show long-term trends in court reorganization that tend to override the purely local and idiosyncratic developments of particular states.

Until recently, few states published statistics on the work of their supreme courts, so our study has had to rely on primary data-the shelves upon shelves of volumes of published opinions. It would have been far too arduous and expensive to deal with all of this data. Instead we drew samples, and, in gathering data, concentrated on those aspects of cases which could most easily be reduced to a number, a code, or a formula.

Our sample consisted of sixteen states, one-third of the total in the nation if we exclude Hawaii and Alaska, which became states only toward the end of our hundred-year period. To pick these sixteen, we divided the forty-eight states into clusters of states that were, for most of those hundred years, most alike in population, industrialization, urbanization, per capita income, racial composition, legislative innovativeness, and other measures likely to affect the legal business of the state court system. ${ }^{3}$ One cluster that emerged was

3. Measures taken from census data were assembled by Richard Hofferbert and made available through The University of Michigan Consortium. Hofferbert, Socio-Economic Dimensions of the American States: 1890-1960, 12 MIDWEST J. PoL. SCI. 401 (1968). The measure of legislative innovativeness was developed by Jack Walker. Walker, The Diffission of Innovations Among the American States, 63 AM. PoL. SCI. ReV. 880 (1969). 
made up of Plains states, such as Kansas, Nebraska, and the Dakotas; another consisted of urban, industrialized states. A third cluster included the Southern states; the Rocky Mountain states formed another distinct group. From each cluster we selected states randomly, in numbers proportionate to the size of the cluster. The sixteen chosen are (alphabetically): Alabama, California, Idaho, Illinois, Kansas, Maine, Michigan, Minnesota, Nevada, New Jersey, North Carolina, Oregon, Rhode Island, South Dakota, Tennessee and West Virginia.

We counted all the opinions of at least one page in length issued by the supreme court of each of these states in twenty-one sample years-1870, 1875, 1880, and so on through $1970 .{ }^{4}$ From the opinions in each sample year, we drew a random sample of eighteen cases, producing a total of roughly $6,000.5$ One member of a team of ten law students then read each case, recording its procedural history, the nature of the parties, and the area of law which underlay the plaintiff's claim. The reader further noted any constitutional issues, the court's decision, the presence of concurring or dissenting opinions, the length of the opinion, the number and type of authorities cited, and how often the case was subsequently cited in Shepard's Citations. Twenty percent of the sampled cases were coded twice; hundreds more were reread and recoded when computer editing routines signalled that some coding error was likely. We believe the result is a representative sample of cases, reliably coded. ${ }^{6}$

Part $I$ of this Article describes in broad quantitative terms the changing relationship between the caseload of supreme courts and the population of the states in which these courts sit. Part II examines the various means states used to control supreme court caseloads, the political problems involved, and the types of courts

4. In addition to very short memorandum opinions, we excluded from our caseload totals opinions on rehearing and opinions denying motions for rehearing. We also excluded, necessarily, decisions issued without opinion (or without published opinion) and decisions granting or denying petitions for review. Consequently, our discussion of "caseload" in fact refers to "opinion load"; "caseload" is not a measure of the courts' "workload." Our study, in effect, involves cases decided with full opinion, cases treated as significant by the supreme courts themselves.

5. Our target was a sample of 6,000 cases (budget and time prevented anything much larger), which worked out to 18 cases from each of 21 sample years for 16 states. The actual sample turned out to be 5,904 cases because Idaho and South Dakota did not become states until 1890 , and thus we had only 17 sample years for those courts. For the most part, we analyze and present the data in three time periods: 1870-1900, 1905-1935, and 1940-1970. In this form, the relevant sample size is 126 cases per state and 2,016 for the 16 states for the last two time periods. It is 1,872 for the first period.

6. For a more complete description of our sampling, coding, and analyzing procedures, see Cartwright, Conclusion: Disputes and Reported Cases, 9 LAw \& Socy. Rev. 369 (1975); Kagan, Cartwright, Friedman, \& Wheeler, supra note 2. 
that have resulted. Part III presents evidence that changes in court organization in response to caseload pressure are accompanied by changes in the kinds of cases state supreme courts hear, the style of their opinions, and the results of the cases.

\section{The Changing Caseloads of State Supreme Courts}

The population of the sixteen states in our sample increased steadily over time, from fewer than eleven million in 1870 to over seventy-three million in 1970. The sixteen supreme courts issued an average of 131 opinions in 1870 , or 170.8 opinions per million persons. From 1870 to 1880 , both the average number of supreme court

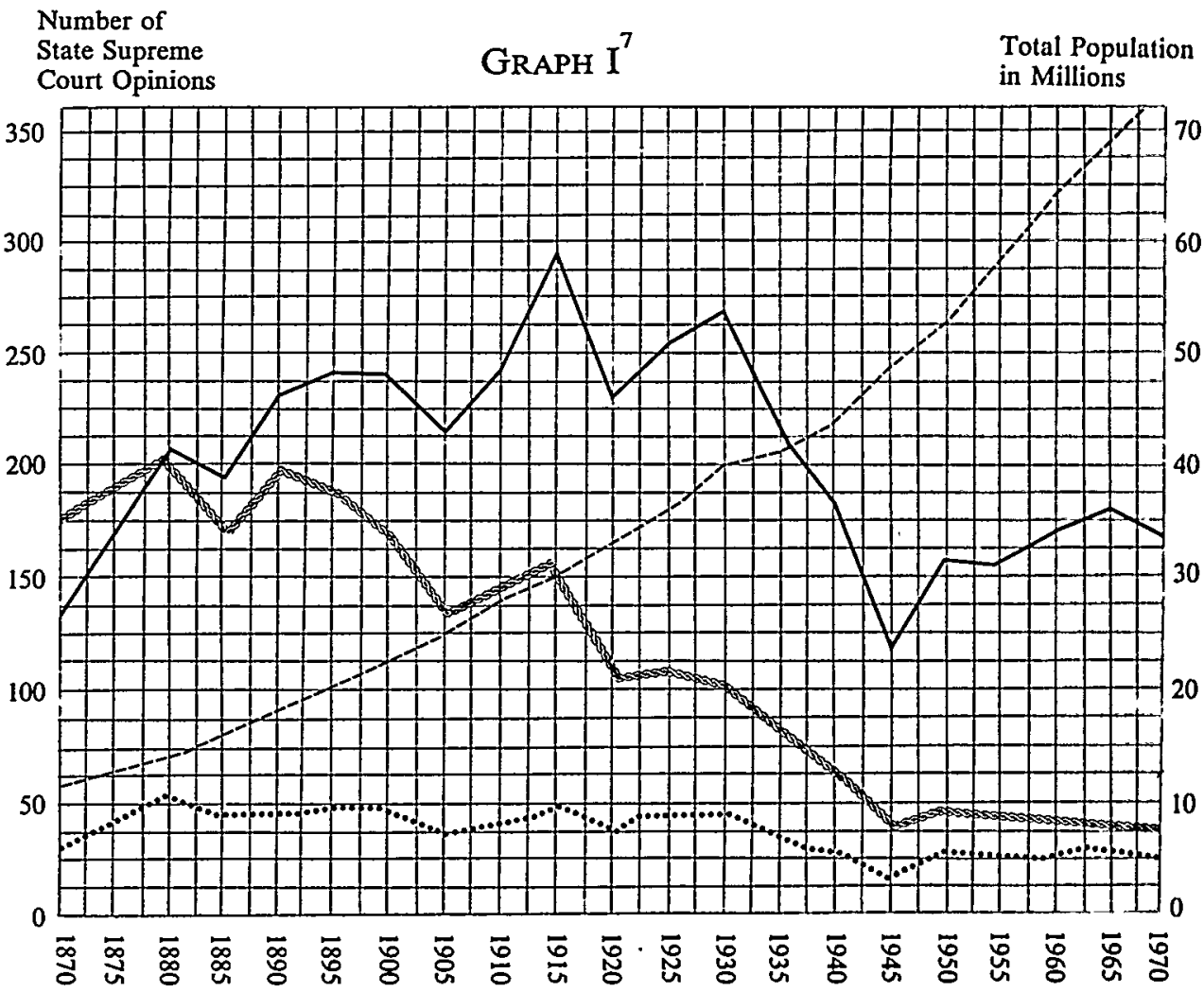

Total Opinions Per Million Population:

Total Population: .......

Average Opinions Per State:

Average Opinions Per Judge:* -.-..

* All calculations in this paper referring to the number of judges per state supreme court include full-time judges, commissioners, active retired judges, emergency judges and pro tempore judges. This somewhat expanded definition of a 'judge' provides a more accurate estimate of workload than opinions per full-time judge alone would provide.

7. Figures for Graph I are on file at the Michigan Law Review. 
TABLE 1

The Effect of Population Size on Opinion Caseloads

The Effect on

\begin{tabular}{lllllll}
$1870-$ & $1885-$ & $1900-$ & $1915-$ & $1930-$ & $1945-$ & $1960-$ \\
1880 & 1895 & 1910 & 1925 & 1940 & 1955 & 1970 \\
\hline
\end{tabular}

Average Opinions

Per State

Correlation ( $r$ )

$\begin{array}{lllllll}.833 & .556 & .722 & .579 & .586 & .595 & .226 \\ .0001 & .0127 & .0008 & .0094 & .0085 & .0075 & .199\end{array}$

Significance of $r$

The Effect on

Average Opinions

Per Judge

Correlation ( $r$ )

Significance of $r$

$\begin{array}{lllllll}.584 & .428 & .471 & .413 & .413 & .522 & .033\end{array}$

opinions per state and the total opinions per million persons rose with the population. But soon after 1880, these numbers began to diverge. After reaching a peak of 201 in 1880, the number of opinions per million persons per year has shown a consistent downward trend, averaging a fairly level forty-two since the end of World War II. The average number of opinions per state, however, continued to rise, although at an irregular rate, and reached its high point in 1915, when the sixteen courts issued an average of 291 opinions. It then began a generally downward move, bottoming at 119 opinions per year at the end of World War II. Thereafter, the average number of opinions rose roughly in relation to population growth. In 1970, the sixteen courts wrote an average of 167 opinions per year.

The main trend shown in Graph I seems clear: from the latter part of the nineteenth century through the middle of the twentieth, state supreme court caseloads (as measured by published opinions) have been brought under greater control, first by breaking the relationship between population and per capita caseload, then by an absolute decline in opinions even as population continued to grow.

Individual states, of course, followed divergent patterns, and consequently, as Table 1 demonstrates, the correlation between population growth and caseloads did not decline in a linear fashion. During the 1870s the correlation was a strong .883; that is, in almost all states, population growth coincided with mounting numbers of supreme court opinions. From 1885 until after World War II, the correlation averaged a considerably lower but still substantial .6. During those years, caseloads in some states continued to increase with population growth, even as supreme courts in other states had begun to write fewer opinions. By the 1960 s, however, the trend to- 
ward caseload control had become more uniform, and the relationship between population growth and increase in caseload had declined to a statistically insignificant $.226 .^{8}$

We reached similar results when controlling for the number of judges on each court. As the lower part of Table 1 shows, population size has generally been positively related to the number of opinions per judge. But the relationship was strongest (.584) in the 1870s; by 1970, the relationship had for all practical purposes vanished.

\section{The Struggle for Caseload Control}

Notwithstanding the distinctive developments in each state, supreme courts in very different states, confronted with rising caseloads, changed in rather similar and predictable ways, although some states were much quicker than others to make those changes. The crucial developments have been in court structure and jurisdiction. Two changes are especially important: grants of power to supreme courts to select their own cases from petitions for review, and the establishment of intermediate appellate courts between the trial courts and supreme courts.

We can distinguish three rough phases in this evolution and three corresponding "types" of state supreme courts. In the first phase, courts had light caseloads and little or no discretion in selecting cases. In the second phase, courts in states with growing populations were burdened by heavy caseloads, but still had little case-selecting discretion. The courts of the third phase had light caseloads (as measured by opinions issued) and great case-selecting discretion; this phase tended to emerge only after extended political struggle. This Part will discuss the three phases in turn, pausing to examine the patterns of transition between the second and third phases.

\section{A. The Low Caseload-Low Discretion State Supreme Court}

The United States in 1870 was still predominantly a country of small towns, small farms, and small businesses, run by small govern-

8. The statistical significance of the relationship between population size and opinion caseloads should be treated cautiously. The declining significance of $r$ (the correlation coefficient) in the 1960-1970 period is caused, in part, by the movement toward increased case control in the larger states. But it also reflects population changes in this period, producing at least two states with extremely large populations, California and Illinois. If the population dimension is logged (to discount the impact of extremely high population values in these two states), the correlation coefficients will decline over time, but the significance levels will be higher. For example, if population size is transformed by natural logarithms, the correlations for average opinions per state are $.739(1870-1880)$ and .500 (1960-1970), with significance levels of .0013 and .0242 respectively. For average opinions per judge, the correlations are .611 (1870-1880) and .135 (1960-1970), with significance levels of .0101 and .3086 respectively. 
ment. The national population was about $40,000,000$, less than onefifth of what it is today. Illinois, the fourth most populous state (after New York, Pennsylvania, and Ohio) and the largest in our sixteen-state sample, had about 2,500,000 citizens. Oregon's population was 90,000 ; Nevada's just over 42,000 . The absolute volume of litigation was certainly far smaller than it is today, ${ }^{9}$ though almost no research exists on this question.

Most states in 1870 had only one level of appeal from their trial courts. Of the sixteen states in our sample, only New Jersey had an appellate court between its trial court of general jurisdiction and its highest court. ${ }^{10}$ In none of our sixteen states could the supreme court select cases from those appealed or screen out frivolous or unimportant appeals - the courts were obligated to hear and decide whatever cases litigants chose to appeal. In constructing their dockets of business, supreme courts in the main were reactive rather than proactive;" the volume and content of their caseloads were "litigantcontrolled."

This system worked decently enough, especially for states with small populations. Caseloads were not impossibly large; few supreme courts in 1870 decided more than 200 cases with full opinions each year. Seven states in our sample never rose above one million in population in the nineteenth century: Maine, Rhode Island, West Virginia, South Dakota, Idaho, Oregon and Nevada. From 1870 to 1900 , their supreme courts averaged fewer than 100 opinions per year. Five of these states remained smaller than one million through 1970: Maine, Rhode Island, South Dakota, Idaho and Nevada. Their annual supreme court caseloads in the twentieth century generally remained below 150 cases, and often below 100 .

9. See F. Laurent, The Business of a Trial Court, 100 Years of Cases (1959) (a study of the circuit court for Chippewa County, Wisconsin); Friedman \& Percival, A Tale of Two Courts: Litigation in Alameda and San Benito Counties, 10 LAw \& Socy. REv. 267 (1976). Alameda County, California, had a population of 94,000 in $1890 ; 716$ cases were filed in superior court that year; $36 \%$ of these came to trial. San Benito, a rural county in California, had a population of 6,400 in 1890 ; only 31 cases were filed and 10 tried. In the 16 states in our sample, there were only six counties in 1870 with over 100,000 people. (There were nineteen by 1900 .)

10. New Jersey's intermediate appellate court, called the Supreme Court, dealt only with cases arising "at law" as opposed to "equity." Equity cases could be appealed directly from the trial judge (a vice-chancellor) to the highest court, the Court of Errors and Appeals. In many states, trial courts of general jurisdiction heard "appeals" from the decisions of local magistrates or justice-of-the-peace courts which had original jurisdiction over small claims and petty offenses. Very often, however, the trial court of general jurisdiction did not review the decision of the justice of the peace or magistrate, but heard the case de novo.

11. For this distinction, see A. Reiss, The Police AND the Public 64 (1971); Black, The Mobilization of Law, 2 J. LEGAL STUD. 125, 128 (1973). 


\section{B. The High Caseload-Low Discretion State Supreme Court}

Other states, however, had larger populations, and some grew quite rapidly. Increases in population generally meant more cases in the trial courts. ${ }^{12}$ If the proportion of lower-court litigants who appeal stayed constant (or fell at a rate slower than the rate of increase in the number of lower-court cases ${ }^{13}$ ), and if appeal remained available as of right, then we would expect population growth to bring more and more appeals. Our data confirm this guess. Supreme court opinions in some of the more populous and faster-growing states reached averages of 400 or 500 a year.

In California and Michigan, population doubled between 1870 and 1895; the number of opinions issued each year jumped from 200 or less in 1870 to over 550 in 1890 and 1895. North Carolina's population took longer to double (its population was 1.1 million in 1870, and 2.2 million in 1910), but its supreme court also doubled its output, from 208 opinions in 1870 to an average of 440 in 1910 and 1915. In Illinois, where the population had reached three million, the supreme court issued 624 opinions in 1875 . When population topped one million in Alabama and Minnesota, the supreme court caseloads quickly grew to over 350 per year. ${ }^{14}$

A court whose caseload jumps in a short time to 300,400 , or 500 cases a year cannot be quite the same kind of court as one which decides 50,75, or 100 cases. Courts, of course, have a certain capacity to accommodate increases in business. Judges can do less research on their own and lean more on the research of lawyers. Judges can spend less time on each case, restrict oral argument, or eliminate it entirely. They can limit the length of briefs and produce shorter or even brief "per curiam" opinions. 15 Still, supreme court

12. The limited research on the subject suggests that litigation rises absolutely with population growth; however, the rate per 1,000 population does not necessarily increase. See Friedman \& Percival, supra note 9, at 292.

13. Many factors, of course, affect the propensity to appeal: the dollar amount at stake in litigation; the costs of appeal (including delay, printing costs, and counsel fees); the attitude of appellate courts toward technical errors at trial; and the proportion of litigants who are, in Galanter's terms, organized "repeat players," like insurance companies, who have full-time specialists in appeals. See Galanter, Why the "Haves" Come Out Ahead: Speculations on the Limils of Legal Change, 9 LAw \& Socy. Rev. 95 (1974). See also Casper \& Posner, A Study of the Supreme Court's Caseload, 3 J. LEGAL STUD. 339 (1974); Kagan, Cartwright, Friedman, \& Wheeler, supra note 2.

14. The phenomenon occurred later for some smaller states. Oregon doubled in size, from about 300,000 to about 700,000 between 1890 and 1910 ; its supreme court's caseload jumped from an average of 137 opinions in 1890 and 1895 to 257 in 1910 and 1915. Nevada's population boomed in the 1960 s, growing from 200,000 in 1950 to 500,000 in 1970. Its supreme court had averaged fewer than 50 opinions each year, in 1970, it wrote 281.

15. As long ago as 1880 , dozens of cases from the New York Court of Appeals were reported briefly each year in the form of short, gnomic opinions. In 1928, that court heard 609 
judges must read at least some briefs, consider competing arguments, decide cases, and write opinions. If their caseload doubles, the judges are harder pressed to keep up, unless they can devise some drastic shortcuts or divisions of labor. ${ }^{16}$

In any event, judges on busy courts had less time to invest in each case than their predecessors who heard fewer cases. At the least, the flood of cases threatened the quality of decision-making, and some supreme courts clearly saw it that way. ${ }^{17}$ Lawyers and legal scholars in the early twentieth century often complained of intolerable delays in the state supreme courts. They also complained that there was not enough time for oral argument or for judges to discuss cases among themselves, and that high courts wasted time on trivial cases. Moreover, some critics contended that the hard-pressed judges relied mechanically on precedent and wrote excessively formalistic opinions which offered only feeble guidance for lower courts and the bar. ${ }^{18}$ Of course, our data cannot measure directly the effect of the bursting caseloads on the thoughtfulness and craftsmanship of decisions in the late nineteenth century. But between 1870 and 1900,

cases, but issued only 280 written opinions. Radin, The Requirement of Written Opinions, 18 CALIF. L. Rev. 486, 492 (1930). North Carolina's supreme court issued 429 opinions and 44 per curiam opinions in 1929. See Open Court, Does Our Supreme Court Need Relief?, 8 N.C.L. REv. 487, 488 (1930). California, like some other states, has recently tried to control its multiplying intermediate appellate court opinions; only "significant" cases (a minority) are supposed to be published. See Jacobstein, Some Reflections on the Control of the Publication of Appellare Court Opinions, 27 STAN. L. REv. 791 (1975). Not everyone approved of per curiam opinions; see the caustic comments of Henry S. Manley in Nonpareil Among Judges, 34 CoRNELL L.Q. 50 (1948). For general information on the use of per curiam opinions, see Institute of Judicial Administration, Appellate Courts. Internal Operating Procedures. Preliminary Report (1957).

16. In some states, too, constitutional requirements made shortcuts difficult. For example, CAL. Const. art. 6, § 24: "all decisions of the Supreme Court . . . shall be given in writing, and the grounds of the decision shall be stated." The provision was repealed in 1966.

17. Recently the judges of Rhode Island's supreme court, who handled only 200 cases a year, complained bitterly that they were not able to devote as much time to each case as they wanted to, to write the kind of opinions they wished to, or to keep up with legal periodicals and other important decisions. Beiser, The Rhode Island Supreme Court: A Well-Integrated Political System, 8 LAW \& Socy. Rev. 167, 173 (1973).

18. See R. Pound, Criminal Justice IN AMERICA 160-64 (1972) (originally published in 1930); Dodd, The Problems of Appellate Courts, 6 AM. L. SCH. Rev. 681 (1930); Foreman, The Law's Delays, 13 MICH. L. REv. 100 (1914); R. Pound, The Causes of Popular Dissatisfaction with the Administration of Justice (1906) (address before the American Bar Association), reprinted in W. MURPhY \& C. PRITCheTt, CourTs, JUdGes AND Politics 69 (1974); Sunderland, The Problems of Appellate Review, 5 TEXAS L. Rev. 126 (1927). See also K. LLEwELLYN, The Common Law Tradition: Deciding Appeals (1960); Horwitz, The Rise of Legal Formalism, 19 AM. J. LEGAL Hisr. 251 (1975).

California, by constitutional provision (CAL. Const. art. 6, § 24), made judges' salaries depend on a monthly affidavit that the docket contained no undecided cases older than 90 days. In the early twentieth century, California Supreme Court judges had slipped 11 months behind in their salaries. See Sloss, M.C. Sloss and the California Supreme Court, 46 CALIF. L. REv. 715, 718 n.5 (1958). 
courts with heavy caseloads did differ from their less burdened counterparts in several distinct ways. Table 2 presents evidence of the possible effects of caseload on three variables that may bear on the quality of opinions in supreme courts: their length, ${ }^{19}$ density of citations, and tendency to cite authorities other than cases.

TABLE 2

The Possible Effect of Caseload on Three Measures of the Quality of State SupReme Court OpINIONS, 1870-1900

\begin{tabular}{|c|c|c|c|}
\hline \multirow{3}{*}{$\begin{array}{l}\text { Average Number } \\
\text { of State Supreme } \\
\text { Court Opinions } \\
\text { Over } 200^{*}\end{array}$} & \multicolumn{3}{|c|}{ Average State Supreme Court Opinion Length, in Pages } \\
\hline & Longer than Median & Shorter than Median & Mean \\
\hline & Ill. (4.2) & $\begin{array}{l}\text { N.C. (3.9) } \\
\text { Kan. (3.8) } \\
\text { Mich. (3.5) } \\
\text { Cal. (3.3) } \\
\text { Minn. (3.2) } \\
\text { Ala. (3.0) }\end{array}$ & 3.6 pages \\
\hline Under $200^{* *}$ & $\begin{array}{l}\text { W. Va. (8.6) } \\
\text { Nev. (5.0) } \\
\text { S.D. (4.7) } \\
\text { N.J. (4.5) } \\
\text { Ida. (4.4) } \\
\text { Ore. (4.2) } \\
\text { Tenn. (4.1) } \\
\end{array}$ & $\begin{array}{l}\text { Me. (3.5) } \\
\text { R.I. (3.2) }\end{array}$ & 4.7 pages \\
\hline \multirow{3}{*}{$\begin{array}{l}\text { Average Number } \\
\text { of State Supreme } \\
\text { Court Opinions }\end{array}$} & \multicolumn{3}{|c|}{$\begin{array}{l}\text { Percent of State Supreme Court Opinions Containing } \\
\text { Citations to More than Eight Precedents }\end{array}$} \\
\hline & More than Median & Fewer than Median & Mean \\
\hline & $\begin{array}{l}\text { Ala. (42.1) } \\
\text { Kan. (30.1) }\end{array}$ & $\begin{array}{l}\text { N.C. }(26.9) \\
\text { Ill. }(23.8) \\
\text { Mich. }(19.9) \\
\text { Cal. (15.9) } \\
\text { Minn. (11.1) }\end{array}$ & $24.3 \%$ \\
\hline Under $200^{* *}$ & $\begin{array}{l}\text { W. Va. (45.6) } \\
\text { S.D. (41.5) } \\
\text { R.I. (39.7) } \\
\text { Me. (35.2) } \\
\text { N.J. (32.5) } \\
\text { Nev. (30.1) }\end{array}$ & $\begin{array}{l}\text { Ore. }(28.0) \\
\text { Tenn. (25.4) } \\
\text { Ida. (17.0) }\end{array}$ & $32.8 \%$ \\
\hline
\end{tabular}

* Except for Kansas, the average was over 300.

** Except for Tennessee, the average was 136 or less.

19. In order to standardize page lengths for varying print types, margins, and page sizes across time and jurisdictions, we sampled cases in each state and time period (using "official 
Percentage of State Supreme Court Cases with Citations TO LEGAL WRITING (TREATISES, ENCYCLOPEDIAS,

LAW REVIEWS)

\begin{tabular}{l|lll}
$\begin{array}{l}\text { Average Number } \\
\text { of State Supreme } \\
\text { Court Opinions }\end{array}$ & More than Median & Fewer than Median & \multicolumn{1}{c}{ Mean } \\
\cline { 2 - 4 } Over 200* & $\begin{array}{ll}\text { Ala. (61.8) } \\
\text { N.C. (42.6) }\end{array}$ & $\begin{array}{l}\text { Kan. (34.3) } \\
\text { Ill. (38.0) } \\
\text { Minn. (35.6) } \\
\text { Cal. (22.0) } \\
\text { Mich. (19.7) }\end{array}$ & $37.0 \%$ \\
\hline Under 200** & $\begin{array}{l}\text { Ore. (56.9) } \\
\text { W. Va. (55.9) } \\
\text { Tenn. (49.0) } \\
\text { Nev. (47.8) } \\
\text { N.J. (44.5) } \\
\text { R.I. (39.8) }\end{array}$ & $\begin{array}{l}\text { Me. (22.3) } \\
\text { Ida. (19.0) }\end{array}$ & $44.4 \%$ \\
\hline
\end{tabular}

* Except for Kansas, the average was over 300.

** Except for Tennessee, the average was 136 or less.

As Table 2 shows, the relationships vary a good deal in strength, but on the average, courts with larger caseloads wrote opinions which were shorter, which used fewer citations, and which referred less often to treatises, legal encyclopedias, and law reviews. Although by no means overwhelming, the evidence is fairly consistent. ${ }^{20}$

It would be rash to conclude from these findings that the decisions of heavy-caseload supreme courts were slap-dash or ill-considered; conciseness can be a virtue and long strings of citations can be a vice. ${ }^{21}$ These findings are consistent, however, with the idea that

reports" rather than West's Regional Reporters) to estimate average characters per page. The page-length variable was then calculated by multiplying the number of pages in each opinion by the average number of characters per page for that state-time sampling point. We divided this estimate of total characters per opinion by the national average of characters per page (2782.1) to create a standardized page consistent for all jurisdictions and time periods.

20. We should note that' some possible consequences of lower caseloads do not show up during this period. Courts with low caseloads presumably had more time to indulge in dissenting and concurring opinions, but we do not find significant differences. In the heavy-caseload courts, $8.3 \%$ of the opinions were not unanimous, compared to $9.4 \%$ for the low-caseload courts. Nor were there significant differences in case results. Supreme courts that averaged over 200 opinions per year reversed, on the average, $43.7 \%$ of all appeals; the low-volume courts reversed $46.1 \%$.

21. Indeed, one of the supposed symptoms of "formalism," a dread disease of courts, is the habit of deciding cases on the basis of authority rather than reasoned principles. This, arguably, induces excessive citation (though, in theory at least, if a judge cited many cases, he may have searched for the ones that really "fit" in some nonformal way). Length sometimes indicates that there was no time to edit. Francis A. Leach grumbled in 1911 that judges "dictate their opinions to stenographers. . . . Few men can dictate with that conciseness with which 
courts with massive caseloads were forced to limit the time, effort, and research devoted to each case. This may have increased the risk of routine, poorly crafted opinions.

\section{Patterns of Adaptation to High Caseload}

How do organizations in general react to an increasing volume of business? A common way is to hire more staff. More staff means more people to supervise and coordinate, and it leads to functional specialization and more layers of authority. The organizations grow and take on the familiar bureaucratic form. ${ }^{22}$

But growth also makes possible economies of scale. The organization works out routines and rules to cover recurring problems. Nonroutine problems are shifted to top officials, who have experts on their staff. ${ }^{23}$ A complex organization also tries to stabilize its relationship with the outside world. It attempts to "smooth out" fluctuations in demands that flow in, sometimes by rationing its services. ${ }^{24}$ Sometimes it feels it will be better off by taking on some jobs too important to leave to outsiders. A steel mill, for example, might want to control the sources of iron or coal; a police department might patrol aggressively instead of relying entirely on citizens' complaints.

A supreme court faced with growing demands on its time, and worried about the quality of its work, might want to use these classic adaptations. That would mean more staff, new levels of courts, perhaps more specialized appellate bodies, and more efficient ways to allocate judicial work. Such a court would want to limit the number and kinds of appeals that it received. Ideally, it would enunciate general rules or principles that lower courts could apply routinely and accurately, so that it need hear only the most serious and important cases.

How could a supreme court ensure that it heard those cases, and only those? It would have to develop a system for identifying signifi-

they can write." And the "free use of mechanical devices such as typewriters" was another enemy of condensation. Leach, The Length of Judicial Opinions, 21 YALE L.J. 141, 144 (1911).

22. See generally Blau, A Formal Theory of Differentiation in Organizations, 35 AM. Soc. REV. 201 (1970); Starbuck, Organizational Growth and Development, in HANDBOOK OF ORGANIZATIONS 451 (J. March ed. 1965).

23. See Starbuck, supra note 22, at 478-81. On the vertical division of labor (between policy-making and administration), see H. SIMON, ADMINISTRATIVE BEHAVIOR ch. 1 (2d ed. i957). On the routinization of decision and "search" procedures, see R. CYERT \& J. MARCH, A Behavioral Theory of the Firm (1963), and J. March \& H. Simon, Organizations ch. 6 (1958). See also Polsby, The Institutionalization of the U.S. House of Representatives, 62 AM. POL. SCI. Rev. 144 (1968).

24. J. Thompson, Organizations in Action (1967). 
cant legal problems and screening out the trivial ones; it would not leave the selection process to the whims and pocketbooks of litigants. A professional staff to help research and write might be more reliable than litigants' lawyers, who differ widely in ability, integrity, and energy. The state's highest court, wrote Cardozo in 1927, exists not for the "individual litigant, but for the indefinite body of litigants. ... The wrongs of aggrieved suitors are only the algebraic symbols from which the court is to work out the formula of justice." 25 In short, busy state supreme courts would strive to become less reactive, less controlled by litigants, more self-directed and bureaucratically organized.

Reform-minded jurists, like those who founded the American Judicature Society, shared these notions. "[S]cientific management is needed in a modern court," wrote Roscoe Pound, "no less than in a modern factory." 26 Reformers pressed for integrated, rational court structures, supported by administrative staffs, to monitor the flow of business and assure that judicial manpower was sensibly allocated. They called in particular for intermediate appellate courts and they felt a supreme court should be able to choose its cases and write its own rules of procedure.

Some of these steps toward reorganization were taken, but some were not. Not until the 1960s did most large and medium-sized states establish intermediate appellate courts and allow supreme courts substantial discretion over caseloads. Through much of the past century, many state supreme courts struggled along year after year, writing 400 or more opinions, using techniques and procedures that had hardly changed in generations. Nonetheless, several different adaptations to the caseload problem can be distinguished.

\section{Early Intermediate Appellate Courts and Discretion}

Among our sixteen sample states, New Jersey, Tennessee, and West Virginia were unusually successful in controlling the volume of

25. B. Cardozo, The Jurisdiction of the Court of Appeals of the State of New YORK 11 (2d ed. 1909), quoted in Dodd, supra note 18, at 689-90 (1930). Actually, if judicial evolution followed theories of organizational rationalization, we might expect state supreme courts to aggregate groups of cases raising similar problems, instead of taking them up one by one. We might expect such courts to hear the views of a variety of affected interests, not just of those who happened to be parties to a particular case. Such a court might call for reports on the consequences of its decisions and try to acquire more administrative and rule-making powers over all the state's courts. In sum, if organization theory dictated judicial structure, state supreme courts would evolve toward organizations resembling regulatory commissions or the top levels of other large organizations. Of course, as we shall see, there are a number of reasons why that did not happen.

26. R. Pound, Organization of Courts 286 (1940); see Cardozo, A Ministry of Justice, 35 HaRv. L. Rev. 113 (1921). 
their supreme courts' caseloads, and they began this process remarkably early. New Jersey, as we saw, had established an intermediate appellate court for cases "at law" (as opposed to equity) in 1844. This court, called the Supreme Court, was later divided into several three-judge panels, each of which heard appeals from different trial courts. ${ }^{27}$ Although New Jersey's highest court, the Court of Errors and Appeals, could not reject appeals from the lower appellate courts, its volume remained extraordinarily small, averaging 145 opinions per year between 1900 and 1935, even though the state's population grew from 1.8 million to 4 million. ${ }^{28}$

Tennessee established an intermediate appellate court for equity cases in 1895 and for all civil cases in 1907. The state expanded this Court of Civil Appeals in 1925. The supreme court's caseload remained at 150 opinions or fewer throughout the century. West Virginia, a smaller state, controlled its supreme court's caseload without intermediate appellate courts. Rather, from 1872 on, it allowed the supreme court to screen appeals and to reject those clearly without merit. ${ }^{29}$

\section{Functional Equivalents for Intermediate Appellate Courts}

California's experience exemplifies the full battery of methods used to control heavy caseloads. In the late nineteenth century, California responded to rapid growth by increasing the size of its supreme court-from three to five judges in the 1860 s. In 1879 , when the court was hearing over 500 cases a year and writing 350

27. See R. Pound, supra note 26, at 221-22; Clevenger, Courts of New Jersey (pt. 2), 18 N.J.L.J. 195, 200 (1895); Dodd, supra note 18, at 682.

28. The New Jersey Court of Errors and Appeals was a very cumbersome body, and this may have discouraged appeals. The court had sixteen members: nine members of the Supreme Court, the Chancellor (head of the courts of equity), and six special judges, who were not necessarily lawyers. According to A. Vanderbilt, ChANGING LAW: A BiograpHY of ARTHUR T. VANDERBILT 169 (1976), collegial interaction on the huge court, which sat only three times a year for two-week terms, was often limited.

29. The W. VA. CoNsT. of 1872 , art. VIII, $\S 6$, allowed appeals to the supreme court only after the court "shall have examined and considered the record and assignment of errors, and is satisfied that there is error in the same, or that it presents a point proper for the consideration of the supreme court of appeals." The court rejected many petitions for review-40 out of 189 in 1903. In the 1920s and early 1930s, according to a study published in 1931, the court refused an average of 230 cases out of the yearly average of 535 cases presented, a refusal rate of over 40\%. See Bell, Our Appellate System, in Proceedings of the Forty-Seventh ANNuAl Meeting of the West Virginia Bar Association 124 (1931). The West Virginia State Supreme Court averaged 147 opinions in 1900-1910, 250 in 1915-1930, and only slightly more than 100 in 1935-1970. See also Kenna, The Supreme Court, in Proceedings of THE Fiftieth ANNual Meeting of the West Virginia BaR Association 122, $124-25$ (1934); Rose, The Modus Operandi of the Supreme Court of Appeals, 49 W. VA. L.Q. 103 (1943). 
opinions, the number of justices was increased to seven. ${ }^{30}$ The court was also authorized in 1879 to divide into three-judge panels or departments to hear cases separately. The full court gathered en banc only for extraordinarily important cases. Other states, too, adopted this innovation. ${ }^{31}$ The department system was also important because it recognized differences among appeals. Some appeals were more "significant" than others; the less important were treated in one way, more important cases in another. In effect, the division into panels created two intermediate appellate courts - or at least alternative supreme courts-for most appeals. ${ }^{32}$

The California Supreme Court judges issued 402 opinions in 1885,122 en banc and 280 in departments. At this point, the legislature authorized the court to delegate to three "commissioners" power to hear cases and make preliminary decisions. Commissioners, in effect, were auxiliary judges (or, perhaps, highly trained and experienced staff members). The court could review and modify the commissioners' opinions, but in practice it simply issued them as its own. ${ }^{33}$ This innovation, too, gave the supreme court some choice of cases it wished to concentrate on. The California Supreme Court continued to produce a prodigious number of opinions (well over 500 in 1895 and 1900), but the judges themselves wrote only 300 per year, 100 en banc, 200 in departments; commissioners handled another 200.

The use of commissioners was discontinued in 1904, when California set up a system of intermediate appellate courts, called courts of appeals. In some types of cases, litigants could appeal only to a court of appeals; in others, they could go directly from the trial court to the supreme court. The California Supreme Court could, however, transfer some of its cases to the court of appeals. It also had discretion to review decisions of the lower appellate courts. ${ }^{34} \mathrm{Al}$ -

30. See Blume, California Courts in Historical Perspective, 22 Hastings L. Rev. 121 (1970).

31. See R. Pound, supra note 26, at 215-17; Sharp, Supreme Courts Sitting in Divisions, 10 N.C.L. REv. 35 I (1932).

32. Sometimes, the California Supreme Court granted a rehearing en banc after a threejudge department had first decided the case. In such instances, the department acted much like an intermediate appellate court, except that the three judges of the department also took part in the full decision. See Sloss, supra note 18, at 715, 719.

33. Other states also used the "commission" system to help supreme courts reduce their backlogs-New York from 1887 to 1893; Oregon, 1907-1909; Minnesota, 1913-1930; South Dakota, 1925-1931; and Illinois, 1927-1933. See R. Pound, supra note 26, at 201.

34. After 1900, California made much less use of its right to sit in divisions. In the cases sampled from 1900,1905, and 1910, two-thirds of the California Supreme Court decisions were rendered by a three-judge department; for the 1915, 1920, and 1925 cases, fewer than one-third were decided by a department. In 1930-1940, all but $7.5 \%$ were decided en banc. See also 
though the supreme court gradually transferred more and more of its cases to the court of appeals, it still averaged over 250 opinions a year from 1910 to 1935 , most of them decided en banc.

\section{The Weak Intermediate Appellate Court System}

Illinois wove a different pattern. It created an intermediate appellate court in 1877 (when its supreme court heard over 600 cases) but allowed these courts only a limited role. Appellants could still proceed directly from trial courts to supreme court as of right unless the amount at issue was less than $\$ 1,000$. Moreover, appeals from the lower appellate court to the supreme court were available as of right.

The Illinois Supreme Court caseload fell to an average of 240 opinions in 1880 and 1885 , but by 1900 and 1905, as population and litigation grew, the volume had climbed back to an average of 475 opinions per year. Statutory amendments in 1909 further limited appeals to the supreme court; however, litigants could still appeal directly in felony, tax, real estate, and most constitutional cases. The supreme court's caseload remained high. The court seemed reluctant to use its discretionary power to deny appeals from the appellate courts; hence, double appeals were common.35 As late as 1958, court reformers in Illinois complained that the supreme court was "hamstrung," that it heard "a wide variety of cases with little legal significance." $" 36$

Preston, California's Appellate Problem, 6 CAL. ST. B.J. 291 (1931); Sloss, supra note 18, at 715. 35. Dodd, The Work of the Supreme Court of Illinois, 21 ILL. L. REv. 207 (1926). See also Dodd, supra note 18, at 692 (comparing the weak use of case-selecting discretion in Illinois with the more vigorous use in New York).

It was estimated in 1946 that $75 \%$ of the cases heard by the Illinois Supreme Court were direct appeals from inferior courts. Speck, $A$ Study of the Illinois Supreme Court, 15 U. CHI. L. REV. 107, 108 (1947).

36. Kohn, Modern Courts for Illinois, 42 J. AM. JuD. SocY. 42 (1958).

Alabama also followed the weak intermediate appellate court pattern. Alabama expanded its supreme court from three to seven justices in 1903 and authorized it to sit in two divisions of four judges each -three associate judges plus the Chief Justice, who joined each panel. 1903 Ala. Acts $493-494$ (No. 530, $\S \S 1,2$ ). But the caseload, which had averaged 330 opinions per year in $1890,1895,1900$ and 1905 , rose to 525 in 1910. In 1911, an intermediate appellate court was created, and the supreme court stopped sitting in divisions. Appeals to the supreme court were still allowed as of right in land title cases, civil actions involving claims of more than $\$ 1,000$, condemnation proceedings, constitutional cases, and very serious felony cases. See 1911 Ala. Acts 95 (No. 121, §§ 1,2). In consequence, the Alabama Supreme Court continued to have large caseloads and averaged 419 opinions per year from 1915 to 1935 . Volume declined in the later 1930s and 1940s, as in virtually every state, but still averaged 275 per year in the 1950 to 1965 period. 


\section{States Without Intermediate Appellate Courts}

Other states dragged their feet even more than Illinois. Minnesota never established an intermediate appellate court, and its supreme court caseload averaged a staggering 425 cases per year from 1890 through 1935 . The load declined during the 1940 s and 1950 s without any notable change in supreme court jurisdiction, but it climbed again in the 1960s, and reached 332 in 1970.37 Kansas, after brief experiments in the 1890s with commissioners and intermediate appellate courts, abandoned both. ${ }^{38}$ Its supreme court averaged 407 opinions a year from 1910 to 1935 . Yet here too, without any major structural change, the caseload dropped off; it averaged a high but not unbearable 225 opinions a year from 1950 to 1970 . North Carolina had no lower appellate court until the 1960s. Its supreme court had averaged well over 300 , and sometimes over 400 , opinions per year since the 1890 s.

Surprisingly, Michigan, one of the big industrial states, had no intermediate appellate court until 1965 . The supreme court issued 438 opinions in 1880 and 413 in 1885 . The legislature increased the court from four judges to five, and then in 1903 to eight. But this seemed only to invite more appeals. The caseload topped 500 cases from 1905 to 1915.39 In 1917, the Michigan legislature freed the

37. Minnesota had two commissioners from 1913 to 1930 , but they did not sit separately from the supreme court or screen routine appeals. They served, in effect, as additional supreme court members, which spread the opinion-writing burden from four judges to six. The court was expanded to seven judges in 1930, and the incumbent commissioners were appointed as ordinary judges. In 1967, the Minnesota Supreme Court began to sit in five-judge departments for about two-thirds of its cases. Heiberg, Social Backgrounds of Minnesota Supreme Court Justices, 54 MinN. L. REv. 901 (1969); Pirsig, The Work of the Supreme Court of Minnesota, 25 MiNN. L. REv. 821 (1941); Wolfram, Notes from a Study of the Caseload of the Minnesota Supreme Court: Some Comments and Statistics on Pressures and Responses, 53 MINN. L. REv. 939 (1969).

38. Beginning in 1887, some Kansas Supreme Court cases were assigned to commissioners. (The court's annual caseload had reached almost 300.) The commissioner plan was abolished in 1893. In 1889, the Kansas legislature limited civil appeals to the supreme court to claims exceeding \$100; even this rather low limit was waived for cases involving title to real estate, libel or slander, false imprisonment, or constitutional interpretation. The court was authorized, however, to sit in divisions. Kansas established two intermediate appellate courts in 1895. In felony cases and civil claims exceeding $\$ 1,000$, however, a Kansas litigant could appeal directly to the supreme court. Moreover, appeal was available as of right from the intermediate to the supreme court in tax, real estate, and constitutional cases. In 1901, this "weak" intermediate appellate court was abolished; apparently the system was unpopular with the Kansas bar. In its stead, the Kansas Supreme Court was expanded to seven judges. It stopped sitting in divisions, however. See R. Pound, supra note 26, at 214; Note, The Kansas Court of . Appeals, 12 WashBuRN L. Rev. 378 (1973).

39. If a court continued to sit en banc and continued to decide cases and circulate opinions collegially, increasing the number of judges would do little to expand case-handling capacity. The addition of new judges to an overworked court often meant only that the court produced what were in effect one-judge opinions rubber-stamped by the judge's colleagues. See Dodd, supra note 18 , at 688 . 
supreme court of its duty to hear appeals from civil cases where the amount in dispute was less than $\$ 500,40$ but this had no significant effect on caseload, for the court continued to write over 400 opinions a year in the 1920s. In 1927, Michigan's supreme court gained the discretion to accept or reject criminal appeals, which had comprised an average of $22 \%$ of its caseload in 1920 and 1925 . That percentage was considerably reduced after 1927 , but the court still wrote more than 400 opinions a year in the 1930s. As was true of almost every supreme court, the Michigan court's caseload declined sharply in the 1940s. ${ }^{41}$ Still, the court averaged 256 opinions a year from 1945 to 1960. Caseload was controlled partly by holding criminal cases to an unusually low $12 \%$ of the docket.

\section{Some Speculations on the Politics of State Supreme Court Reorganization}

We are not sure why supreme court caseloads remained so high so long in so many states, and why structural reform did not come sooner. One crucial factor, it would seem, is that in many states the structure of the judicial system was embedded-one might say frozen-in the state constitution. For many reasons, too, legislators and political leaders were uninterested in reform, or opposed to it outright. Politicians certainly did not see backlogs and overloads in the supreme court as the most pressing problem of the day. Spending money on salaries for new intermediate appellate judges was never politically inviting. The work of some state courts was controversial. Judges were sometimes perceived as reactionaries and as enemies of social legislation; to give such judges more power and discretion would only encourage "government by judiciary." 42 Supreme court

40. Pub. Act No. 172, 1917 Mich. Pub. Acts 347. The $\$ 500$ minimum for appeals as of right was repealed in 1919, Pub. Act No. 14, 1919 Mich. Pub. Acts. 19-20, but reinstated in 1923. Pub. Act No. 155, 1923 Mich. Pub. Acts 247. However, the legislature stipulated that even in small civil cases, a litigant could appeal to the supreme court as of right in will contests, in cases construing the state constitution or a state statute, or in "any matters of great public importance." Pub. Act No. 155, 1923 Mich. Pub. Acts 247. Legislatures were reluctant to erect high jurisdictional amounts because of a widespread feeling that the "right" to appeal should not by law depend on wealth, directly or indirectly, though of course it did in practice if not in theory.

41. Systematic caseload data for lower state courts over time do not exist. Civil litigation in the United States district courts declined by almost 50\% in the late 1930s and 1940s, both absolutely and in terms of litigation rates per 1,000 population. See Grossman \& Sarat, Litigation in the Federal Courts, 9 LAW \& Socy. REv. 321, 336 (1975). A study of the county court in Chippewa County, Wisconsin, noted that litigation fell off during World War II. F. LAURENT, supra note 9. This, rather than changes in court structure, seems to explain the failure of supreme court caseloads to increase along with population in the late 1930s and the 1940s.

42. Literature abounds on the due process activism of late-nineteenth- and early-twentiethcentury state supreme courts. See L. Beth, THE Development of The AMERICAN ConstItution, 1877-1917 (1971); A. Paul, Conservative Crisis and the Rule of Law, Atti- 
reform was often part of a general reform package that included reshaping the lower courts, and thus local magistrates, justices of the peace, court clerks, and others who felt they might suffer in a reorganization outshouted the few reformers. Political and party officials threatened with loss of patronage were also part of the opposition. ${ }^{43}$

Indeed, supreme court judges themselves did not always strongly advocate reorganization. Their self-interest called for caseload control, of course; in modern court systems, more cases do not bring more fees or higher salaries, but simply more work. A court that decides 200 or fewer cases a year and concentrates on difficult and important problems tends to be more prestigious than one struggling through 400 mostly routine cases. ${ }^{44}$ But judges also have a tradition of reticence. It is thought unseemly for them to lobby, ${ }^{45}$ to seek more power, or to press for reforms that encourage the use of courts. ${ }^{46}$

In addition, in some states, there seem to have been strong feelings about a right to appeal. It was argued that every litigant, big or small, should have a chance to take his case, big or small, to the state supreme court. Finally, some jurists feared that reforms would impair the law's uniformity and certainty. A single supreme court was better, the argument ran, than a multitude of commissioners, divisions, or lower appellate courts, all issuing their own pronouncements on "the law." 47

TUDES OF BAR AND BENCH, 1887-1895 (1960); B. TWISS, LAWYERS AND THE CONSTITUTION: How Laissez Faire CAME to the Supreme Court (1942). A 1912 amendment to the Ohio constitution provided that the Ohio Supreme Court could not declare a statute unconstitutional unless six of the seven justices agreed. Aumann, The Course of Judicial Review in the State of Ohio, 25 AM. Pol. SCI. Rev. 367 (1931).

43. See Kohn, supra note 36 (describing the failure of one court-reform plan).

44. Judicial prestige, however, is not necessarily related closely to caseload or case-selecting discretion. See the (somewhat unsatisfying) effort to measure state supreme court prestige in Mott, Judicial Influence, 30 AM. PoL. ScI. REv. 295 (1936).

45. Even in the late 1960s, some judges felt they would violate the principle of separation of powers if they lobbied at all. Glick, Policy-Making and State Supreme Courts: The Judiciary as an Interest Group, 5 LAw \& Socy. Rev. 271, 275 (1970) (a survey of the attitudes of state supreme court judges and state legislators).

46. In the ideology of American law, litigation is not to be encouraged; delays and jam-ups have the "function" of making litigation unpalatable. See Friedman, Legal Rules and the Process of Social Change, 19 Stan. L. Rev. 786, 798-800 (1967).

47. The Chief Justice of the Virginia Supreme Court opposed sitting in divisions, fearing that "the course of decision would not be uniform." See Sharp, supra note 31, at 363. Intermediate appellate courts were also criticized as an invitation to double appeals (thus increasing the cost and uncertainty of litigation). See Sunderland, Intermediate Appellate Courts, 6 AM. L. SCH. REv. 693, 694 (1930), and Sunderland, supra note 18, at 138. The short-lived Kansas experiment with intermediate appellate courts, see note 38 supra, opposed by the bar, is yet another case in point. In addition, see Preston, supra note 34, at 296: "[T] feeling in the minds of the bar that when cases come up [to the Supreme Court] from the 
But ideologies have been shifting over the years. Gradually, judges have espoused a somewhat different view of themselves and their roles. "Sociological jurisprudence" and legal realism have made their mark. At least some state supreme court judges now feel that making policy is an inevitable part of their work, ${ }^{48}$ and they wonder whether they should not approach it more systematically. To do so, they must be able to winnow out the trivial cases and concentrate on the important. That cannot be done without structural reform, intermediate appellate courts, control over dockets, and larger staffs.

Meanwhile, reform has become better organized. Since 1917, the American Judicature Society has published a journal which stresses judicial reform. Since the 1920s, state judicial councils, staffed by judges and legislators, have gathered statistics on court business, issued reports and recommendations, and lobbied for reform. ${ }^{49}$

Nevertheless, state supreme courts have not acquired caseload control easily; it has been a long, complicated process, heavily dependent on the political skill of judicial reformers and on the local political climate. ${ }^{50}$ Apparent victories have often been subverted. Kansas established an intermediate appellate court in 1895 and abolished it six years later. Illinois set up a lower appellate court, but still allowed direct appeals to the supreme court for cases involving certain politically important interests. Not until the 1960s did the reformers gain real momentum. Only eleven states had intermediate courts in 1948; by 1970, twenty-three did. ${ }^{51}$

Why reform accelerated in the 1960 s is not completely clear. In 1962, the American Bar Association endorsed the model statewide

District Court of Appeals they are entitled to be heard in bank, and that the bar would not be satisfied with a department opinion."

48. See H. Glick, Supreme Courts in State Politics: An Investigation of the JuDICIAL ROLE (1971).

49. See Glick, supra note 45; Pound, The Function and Prospects of the Judicial Council, 23 J. AM. JUD. SOCY. 53 (1939).

50. See L. Pelekoudas, Judicial Reform in Ten States (1963) (Ph.D. Dissertation, University of Illinois).

Kentucky recently voted to establish a system of intermediate appellate courts and to give its heavy-caseload supreme court great case-selecting discretion. Some observers attributed the judicial reformers' election victory to the overconfidence of perennially successful (in previous years) opponents of reform, primarily the local magistrates. Even so, the reform measure carried by only 35,000 votes, a margin it owed to voters in big cities and suburbs, and was defeated in 101 of Kentucky's 120 counties. Kentucky Brings Order to Its Courts, L.A. Times, Dec. 16, 1977, Part VII, at 1, col. 1. (1971).

51. Fair, State Intermediate Appellate Courts: An Introduction, 24 W. PoL. Q. 415, 415 
Judicature Act of the American Judicature Society. ${ }^{52}$ The work of the Warren Court, and the ferment of the 1960s, may have helped build a reform-minded climate of opinion. Organized litigants, such as civil rights groups and "public interest" law firms, urged the courts to engage in social and legal reform. ${ }^{53}$ Support for reform may also have sprung from more conservative sources. Some judges who were unhappy with the dramatic increase of criminal appeals and auto accident cases in the 1960s may have wanted the supreme courts to be able to screen out such cases and to concentrate once again on matters important to business and industry. ${ }^{54}$

\section{The Low Caseload-High Discretion State Supreme Court}

By the end of the 1960s, most of the medium-sized and larger states in our sample of sixteen had created intermediate appellate courts and given their supreme courts substantial discretion to select cases from petitions for review. (Kansas and Minnesota were the only exceptions.) Consequently, supreme court caseloads, as measured by opinions issued, were sharply reduced.

New Jersey is one example. With Chief Justice Arthur Vanderbilt providing strong leadership, a new constitution was adopted in 1948 which abolished separate courts of equity, set up a comprehensive system of intermediate appellate courts, reorganized the supreme court, and gave it broad power to make its own rules and select its own cases. ${ }^{55}$ An administrative office for the courts was

52. See Winters \& Allard, Judicial Selection and Tenure in the United States, in THE Courts, The Public and the Law Explosion 151 (H. Jones ed. 1965).

53. On the rise of the "public interest bar," see Rabin, Lawyers for Social Change: Perspectives on Public Interest Law, 28 STAN. L. Rev. 207 (1976); Comment, The New Public Interest Lawyers, 79 YALE L.J. 1069 (1970).

54. Criminal appeals in particular were often considered legally unmeritorious. In fact, criminal appellants won only $33.8 \%$ of their appeals in our sample between 1940 and 1970 . In all other categories, appellants won almost $40 \%$ of the time. The success rate of criminal cases in state supreme courts was lower than that of any other major case category (e.g., family, estates, property, torts, public law, contracts). Moreover, criminal appeals were particularly unsuccessful in the 1960 s, when the number of criminal cases on supreme court dockets increased dramatically; only $28 \%$ of the criminal defendants prevailed in the 1965 sample, and 26.3\% in the 1970 cases. A Michigan Supreme Court justice remarked, "After an experience of many years, I can say that . . . there is but seldom a semblance of merit in these petitions to appeal or for habeas corpus in criminal cases." Butzel, Judge Butzel Reminisces, MiCH. ST. B.J., Dec. 1955, at 30. R. Leflar, Internal Operating Procedures of Appellate CoURTs 10 (1976), states: "In years gone by there was a tendency to downgrade the importance of criminal cases. The 'great cases' arose from civil litigation, and appellate judges shied away from criminal appeals when they could." Leflar goes on to say that these attitudes have been changing, but he acknowledges that "the percentage of frivolous criminal appeals is undoubtedly higher than that of frivolous civil appeals," and he urges judges not to "shrug off" criminal appeals as "less important matters to be handled . . . more summarily than others." Id. at 11 .

55. See Brennan, Does Business Have a Role in Improving Judicial Administration?, 28 PA. 
established. The New Jersey Supreme Court averaged only 141 opinions a year from 1950 to 1970; it became known as a distinguished and innovative court. ${ }^{56}$

The California Supreme Court, which averaged 166 opinions per year in the 1950s and 1960s, was one of the most influential supreme courts in the country. It had great discretion over its caseload, and its professional staff was enormous by traditional standards. By 1970, each of the six associate justices had three research attorneys (law clerks), at least one of whom was an experienced lawyer who held the position permanently, while the others were recent law school graduates with outstanding academic records. The chief justice had twelve research attorneys supervised by a senior research attorney. A substantial number of "externs," second- and third-year law students from California law schools, also served the staff. Clerks screened petitions for review and wrote conference memoranda. When the justices decided to hear a case, they assigned it to a single justice who, with his staff, prepared a pre-argument "calendar memorandum." This usually became the basis for the court's opinion. 57

In the 1960s, several other states followed the lead of New Jersey and California. In Oregon, postwar population growth pushed the supreme court's volume over 300 opinions per year in 1960. An intermediate appellate court for tax cases was established in 1961, for most other types of cases in 1969.58 A 1964 amendment to the Illinois constitution gave the supreme court more control over its cases. The absolute right of appeal to the supreme court was abolished for real property cases, felony cases, and cases in which the state was a party. ${ }^{59}$ Tennessee added an intermediate court for criminal cases in

B.A.Q. 238, 241 (1957). In addition, methods of hearing and deciding cases were reorganized to increase the preparation and discussion the judges granted each case. See A. VANDERBILT, supra note 28, at 170-73; Vanderbilt, Our New Judicial Establishment: The Record of the First Year, 4 Rutgers L. REV. 353 (1950).

56. New Jersey Supreme Court opinions were more widely cited than those of any of the other state supreme courts in our sample except California. See Table 5 infra.

57. See Goodman \& Seaton, Foreword: Ripe for Decision, Internal Workings and Current Concerns of the California Supreme Court, 62 CALIF. L. Rev. 309 (1974).

58. Smith, An Historical Sketch of Oregon's Supreme Court, 55 ORE. L. REv. 85,93 (1976). Confronted with a rising caseload in the early 1960 s, the Oregon Supreme Court often divided into two three-judge departments that heard "less important" cases, supplemented by "pro tem justices." OREgon Judicial COUNCIL, The Courts of OREgon 5 (1967). On earlier periods in Oregon, see Tongue, Delays on Appeals to the Oregon Supreme Court, 36 ORE. L. REv. 253 (1957).

59. Appeals were still available as of right in tax and constitutional cases, habeas corpus cases, and in cases concerning the State Industrial Commission or the State Commerce Commission. See Ill. CoNST art. 6, § 5; ILL. SUP. CT. R. 28-1, Ill. Rev. STAT. ch. 110, § 101.28-1 (1965). 
1967. (It had had one for civil cases for years.) Michigan established a system of intermediate appellate courts in 1965. The supreme court, granted nearly complete discretion over its docket, issued ninety-six opinions in 1970, compared with an average of almost 230 in 1960 and 1965. North Carolina added appellate courts and gave its supreme court full control of its docket in 1967. The caseload dropped from 473 to 118.60 In 1969, Alabama expanded the jurisdiction of its intermediate courts and gave its supreme court broad caseselecting discretion. ${ }^{61}$

This increasing discretion and diminishing caseload implied corresponding changes in the function of the supreme courts. It suggested an emerging societal consensus that state supreme courts should not be passive, reactive bodies, which simply applied "the law" to correct "errors" or miscarriages of justice in individual cases, but that these courts should be policy-makers and, at least in some cases, legal innovators.62 After the 1967 reform in North Carolina, the supreme court, it was said, could now concentrate on "truly significant questions of law."63 Even in smaller states, the ideal was a low-volume, well-staffed supreme court which "delegated" routine appeals and supervision of trial courts to lower appellate courts and concentrated on important, far-reaching cases. Rhode Island's supreme court had no case-selecting discretion; one justice complained in 1974 that half of the court's cases "don't belong in the highest court of a state."64 Moreover, requiring appellants to peti-

60. See Groot, The Effects of an Intermediate Appellate Court on the Supreme Court Work Product: The North Carolina Experience, 7 WAKE FOREST L. REv. 548, 562-69 (1971).

61. Alabama's intermediate appellate courts were designated the exclusive appellate courts for criminal cases, all civil cases under $\$ 10,000$, and all administrative appeals, except where the supreme court chose in its discretion to take a case. AlA. CODE tit. 12, § 3 (1975). See Bloodworth, Remodeling the Alabama Appellate Courts, 23 ALA. L. Rev. 353 (1971). On the preceding period, see Note, Alabama Appellate Court Congestion: Observations and Suggestions from an Empirical Study, 21 ALA. L. REv. 150 (1968).

62. See R. LEFLAR, supra note 54, at 1-2 (a volume prepared in conjunction with the Appellate Judges' Conference of the American Bar Association). Appeals, writes Leflar, are no longer "heard only for the purpose of correcting errors committed in trial courts." Now state supreme courts are "to give authoritative expression to the developing body of the law." Leflar notes with approval that since "opposing parties and their counsel do not invariably present all sides of an issue," courts more often invite briefs on issues the judges think important and decide cases formerly regarded as moot. He adds that as "the lawmaking function of appellate courts is more clearly recognized . . . the apparent justification for strictures against . . . rendering advisory opinions diminishes correspondingly." Id. at 5-6. See also Baum, Policy Goals in Judicial Gatekeeping: A Proximity Model of Discretionary Jurisdiction, 21 AM. J. PoL. ScI. 13 (1977).

63. Groot, supra note 60, at 554 (quoting The Judicial Department, State of North Carolina, annual Report of the Administrative Assistant to the Chief Justice 7 (1968)).

64. Beiser, supra note 17 , at 174. A California lawyer, speaking about cases decided by his father, who sat on the California Supreme Court from 1906 to 1919 , observed that many of 
tion the court for a share of its precious time encouraged a new, more policy-oriented judicial role. Appellants could not merely argue that the trial court had committed "errors." They had to demonstrate that they deserved to be heard for special reasons. When addressing the modern high-discretion supreme court, therefore, appellants often emphasized the case's legal significance and social consequences, for which the court was urged to assume responsibility.

\section{E. A Typology of State Supreme Courts}

Table 3, which shows the population and caseload for each state in seven time periods, summarizes the movement toward caseload control. We grouped the states by the "type" into which they fell during most of the 1870-1970 period. Because of their dramatic shifts, we placed Oregon and California in the type that best characterized them in the last two decades. The three types, which represent different combinations of population, supreme court caseload, and discretion, are as follows:

Type I: Low population states (under one million) with no supreme court case-selecting discretion, no lower appellate court, and relatively light caseloads.

Rhode Island, Maine, South Dakota, Idaho, and Nevada were in this category throughout the century. Their supreme courts averaged fewer than 100 opinions per year.

Type II: Medium-sized (over one million) and large states with little or no supreme court case-selecting discretion, and heavy caseloads.

Illinois, Michigan, Minnesota, Kansas, North Carolina and Alabama were in this category for most of the century. Oregon joined it in population terms in the 1930s and in caseload terms (over 220 opinions) in the 1915-1930 and 1960-1970 years. These supreme courts averaged well over 200 opinions a year in most time periods, and often 350 or more.65

Type III: Medium-sized or large states with substantial controls over supreme court caseloads (lower appellate courts handled most appeals or supreme courts had wide discretion to choose cases) and relatively light caseloads, measured by published opinions.

these cases "would now be considered far too trivial to warrant attention by the court of last resort." Sloss, supra note 18 , at 716 . This view, it should be noted, is not universally held. One Rhode Island Supreme Court judge stated in the early 1970s that his court's primary function was and (implicitly) should be correcting errors "under the law, as it stands," rather than making law. Beiser, supra note 17, at 170-71.

65. In the late 1960s, Alabama, Michigan, North Carolina, and Oregon instituted substantial reforms which took them out of this category, but those changes occurred too late to have much effect on the data for 1940-1970, the period analyzed in the following section. 


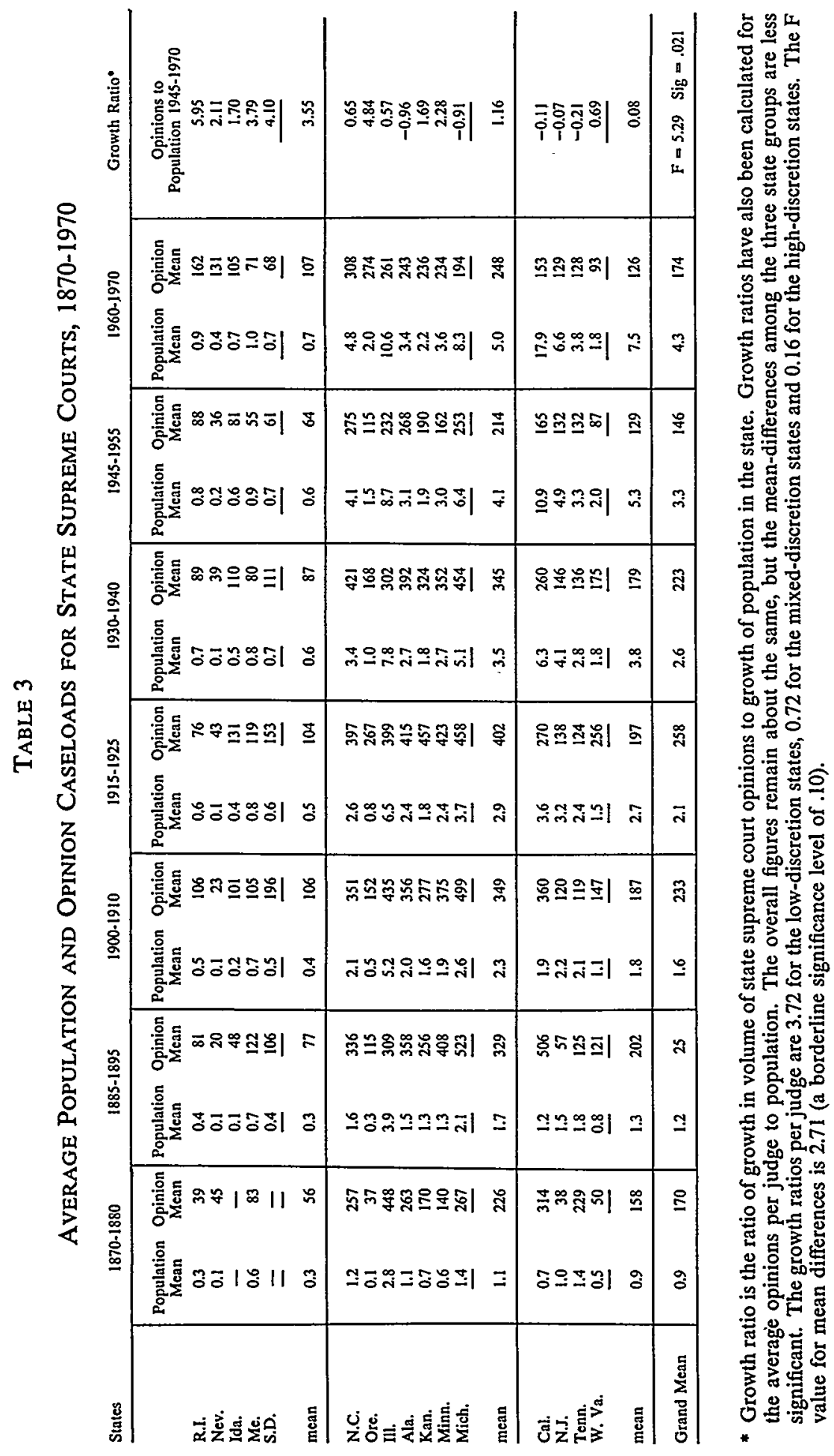


New Jersey, Tennessee and West Virginia were in this category for most of the century. California's supreme court joined it about 1940, when it began exercising its discretion to assign most appeals to the court of appeals. These supreme courts averaged under 200 opinions a year, and often fewer than 150 .

Interestingly, the states in these types did not correlate closely with the clusters of states (defined by economic and social variables) from which we picked our sample. States from the urban-industrial cluster, for example, did not necessarily share the same type of supreme court. Rhode Island has a Type I court, Illinois and Michigan had Type II courts, and New Jersey has had a Type III court. Alabama, a poor southern state, mingled with the rich in Type II. Tennessee and West Virginia, also members of the "southern" cluster, joined California in Type III. Differences in the organization and work of state supreme courts, therefore, cannot be explained as direct results of differences in the social and economic character of the states.

The far right column in Table 3 shows the relationship between changes in state population and changes in supreme court caseloads for the periods 1945-1955 and 1960-1970. In Nevada, for example, population doubled while supreme court opinions quadrupled. More precisely, the growth in opinions was 2.11 times as great as the population growth rate. In other Type I states, caseloads grew significantly from 1960 to 1970 even though population growth was negligible. Rhode Island's caseload increased by more than $80 \%$, an increase almost six times greater than that of the population. Like Nevada, Rhode Island had no obvious mechanisms to stem the upsurge in appeals, whatever its causes, and these two supreme courts issued 200 or more opinions per year by the early 1970s. They now stand on the brink of moving from Type I into Type II; they may have begun to feel pressure for greater control over caseloads.

The ratios of opinion to population growth were more variable for Type II states in the 1945-1970 period. Illinois, Alabama, Michigan, and North Carolina increased their supreme court's discretion over cases in the 1960s, and caseload growth in those states stayed relatively close to population growth-it was slightly ahead in Illinois and North Carolina, slightly behind in Alabama and Michigan. On the other hand, in Kansas and Minnesota, where there were no lower appellate courts and where supreme courts could not select cases, opinions grew considerably faster than population. Oregon 
experienced a large increase in population and the largest relative caseload growth. In 1960, its supreme court issued 339 opinions. The legislature created a system of intermediate appellate courts in 1969 , and in 1970 the supreme court published only 201 opinions.

Substantial differences exist between the first two types of supreme courts and the third. The average opinion-to-population ratio for Type II states was positive. For Type III states, however, with one exception, it was negative. Only West Virginia, whose population had actually declined while its supreme court caseload remained low but relatively constant, had a positive ratio. Although Type III states, on the average, were ten times the size of Type I states and in absolute terms had a much larger population growth, their average number of supreme court opinions (126) from 1960 to 1970 was only 19 more than the average (107) for the small states in Type I. The Rhode Island Supreme Court produced more opinions than the California Supreme Court, which sits in a state with twenty times Rhode Island's population. And Type III supreme courts issued only about half as many opinions as the Type II courts.

As we said, these differences are substantial. But are they important? What are the consequences of the evolution of judicial structures toward the greater caseload control of Type III? Does the freedom of a Type III court to concentrate more of its energies on "important" cases make the court's work qualitatively different? Part III addresses this subject.

\section{The Consequences of Caseload Control}

We have suggested that state supreme courts fall into three different types in terms of caseload and discretion to select cases. There has been a pronounced evolution toward a structure that grants high discretion and permits lighter caseloads. One might expect supreme courts even in smaller states to take this form if caseloads continue to grow. In this Part, we inquire whether differences in court type produced measureable changes in the types of cases that came before the court, in opinion style, and in case results. We concentrated on the 1940-1970 period, during which our courts fell rather neatly into three types.

\section{A. Type of Cases}

If we take the last century as a whole, we find a marked decline in the percentage of state supreme court cases that stemmed from private business or property transactions (contract, debt collection, 
real property), the categories that dominated court dockets in the late nineteenth century. Conversely, the number of tort, criminal, and public-law cases grew considerably. In the most recent third of our survey period-1940-1970 - criminal and constitutional cases increased the most sharply. ${ }^{66}$

To a large extent, these trends are independent of the structure of state supreme courts. They reflect nationwide changes in society, economy, and law. The automobile produced more tort cases in almost every state from the 1920 s on. Beginning in the late 1930 s, as the rate of business failures declined, debt-collection cases declined in every court, regardless of caseload or the level of a state's economic development. That trend probably reflected a stronger, more rational banking and credit system; deposit insurance; and perhaps the long boom that followed World War II. Criminal cases increased dramatically in almost all state supreme courts in the $1960 \mathrm{~s}$, again regardless of structure, partly because of a rising crime rate and perhaps also because the Warren Court imposed on the state courts new due process rights for criminal defendants. ${ }^{67}$

These trends were general but by no means uniform. In theory, state supreme courts with discretion to select their cases could more easily resist the kinds of cases litigated in great number in the lower courts. Had they chosen, they could have concentrated on statistically less frequent, and presumably more significant, types of cases, and they could have stimulated new areas of litigation. We hypothesized that courts with high discretion and low caseload would tend, on the average, to lead the shift away from private-law cases toward criminal- and public-law cases and that they would also lead the shift toward cases raising constitutional issues. We assumed that high-discretion courts would be less likely to consider private-law cases worth their scarce time.

The basic data appear in Table 4. The relationships between

66. To be precise, from 1870 to 1900 , contract cases (three-fourths of which were debt collection and creditors' rights matters) constituted $33.6 \%$ of state supreme courts' dockets and real property cases accounted for $21.4 \%$. In the 1940-1970 period, contract and debt-collection matters declined to $15 \%$ and real property to $10.9 \%$. Conversely, tort cases grew from $9.6 \%$ of state supreme courts' dockets in $1870-1900$ to $22.3 \%$ in 1940-1970; auto accident cases alone were $7.5 \%$; workplace-accident and workmen's compensation cases were $8.3 \%$. Criminal cases swelled from $10.7 \%$ in $1870-1900$ to $16 \%$ in 1955-1960, then to $28 \%$ in 1965 and 1970. Many of the criminal cases in the 1960s posed constitutional issues; while such issues arose in only $18.5 \%$ of the criminal cases from 1870 to 1950 , they appeared in almost $50 \%$ of the criminal cases from 1965 to 1970. Public-law cases (including taxation, eminent domain, election and public employment disputes, and administrative regulation of business)-which also often posed constitutional issues-rose from $12.4 \%$ in $1870-1900$ to $19.4 \%$ in $1940-1970$. Kagan, Cartwright, Friedman, \& Wheeler, supra note 2, at 133-47.

67. Id. at 147. 


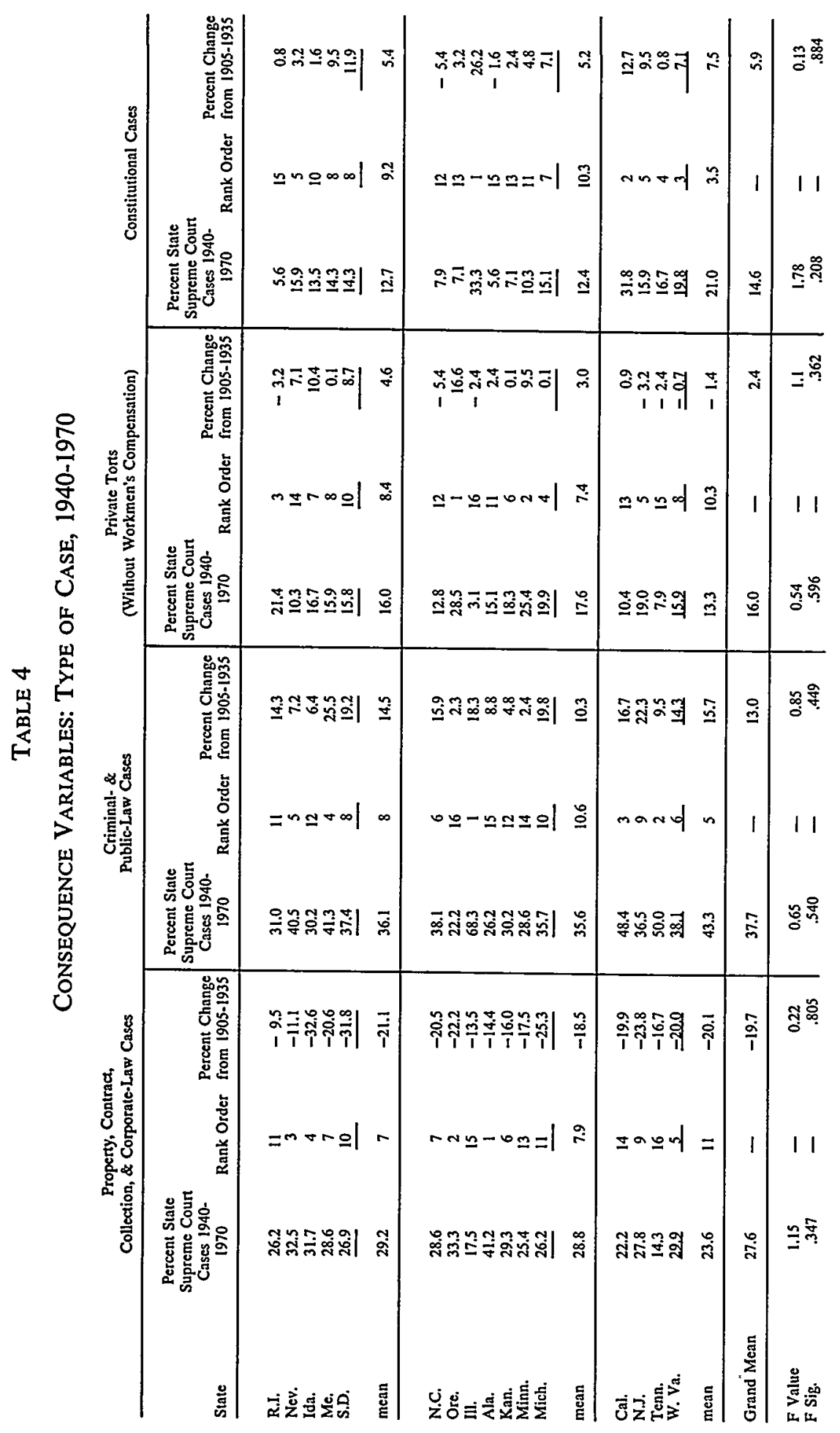


type of court and type of case are not powerful, but they do point in the predicted direction. From 1940 to 1970, the percentage of property, contract, collection, and corporate cases declined in every state (compared to 1905-1935), but courts with greater power over case selection tended to have lower percentages of these cases. Criminaland public-law cases increased in all states, but the courts with most case-selecting discretion had more of these, on the average. Tort cases (resulting primarily from automobile accidents) increased somewhat in the supreme court dockets of most Type I and II states, but they declined in higher-discretion courts, except in California, where they stayed steady at an already low level.

However, the differences are by no means great, and marked individual variations exist within each type of court. Illinois, for example, had more criminal cases and fewer private-law cases than most states with greater caseload discretion. ${ }^{68}$ Differences within types of states tended to be larger than differences among types. We have, then, definite but quite modest evidence that the states with greater caseload discretion tended to lead the generally shifting emphasis from "private law" to "public law" cases. 69

Table 4 also shows that in the $1940-1970$ years, Type III supreme courts more frequently decided constitutional issues. Cases with constitutional issues made up more than a fifth of the supreme court docket in high-discretion states, compared to about an eighth of the cases in other states. Caseload control does, therefore, seem to provide the courts with the ability to concentrate on frontier regions of law and on cases of constitutional significance. Still, despite their more "primitive" structure, other states participated in these trends. Court structure influences, but does not alone determine, the types of cases state supreme courts hear. ${ }^{70}$

68. To some extent, this was an artifact of lllinois laws on jurisdiction. For most of the 1940-1970 period, a litigant could appeal as of right to the Illinois Supreme Court from both trial courts and intermediate appellate courts in all felony, constitutional, and tax cases; in appeals from administrative agencies; and in other noncommercial matters.

69. It is possible, of course, that causation runs the other way: that is, from the changing type of state supreme court cases to structural change in the court system. As criminal appeals increased on some Type II court dockets in the 1960s, the demand for intermediate appellate courts and case-selecting discretion increased. Nevertheless, the four courts which fell within Type III for most or all of the 1940-1970 period (California, New Jersey, Tennessee, West Virginia) had intermediate appellate courts or discretion before the nationwide upsurge in criminal cases. The tendency of these supreme courts to expand the percentage of criminaland public-law cases faster than average suggests that supreme court discretion actually affected the types of cases on which those courts concentrated.

70. As we suggested earlier, a state's social, economic, and political characteristics-in addition to its court structure-undoubtedly affect the mix of cases selected by its supreme court. But the relationships are complicated, and judicial culture and attitudes also play a part. See 


\section{B. Opinion Style}

We might expect that courts with high discretion and small caseloads would be able to devote more time to their decisions and, hence, to write longer opinions, cite more cases, and make more use of law review articles (an indication, perhaps, of more sophisticated scholarship). The opinions of such courts might be well-regarded, and therefore frequently cited, by other courts.

Table 5 provides some evidence for these suggested relationships. With the exception of Tennessee, the high-discretion courts tended to write longer opinions than their busier, heavy-caseload counterparts and low-caseload supreme courts in small states. California's court wrote the longest opinions of the sixteen. But again, differences within groups are greater than those among groups. ${ }^{71}$

Table 5 also shows that, on the average, the high-discretion courts cited law review articles more often than Type I or II courts. However, these averages may be a bit misleading. Two Type III courts, California and New Jersey, cited law review articles in over $15 \%$ of their opinions, more than double the sixteen-state mean, while two other states with high-discretion courts, West Virginia and Tennessee, cited law reviews less often than the average. Perhaps more striking than the comparisons is the paucity of law review citations by any supreme court. For good or for ill, however, the rate is

Kagan, Cartwright, Friedman, \& Wheeler, note 2 supra. Consequently, attempts to show direct relationships between social, economic, and political variables, on one hand, and supreme court agenda on the other, have produced inconclusive results for the most part. See Atkins \& Glick, Environmental and Structural Variables as Determinants of Issues in State Courts of Last Resort, 20 AM. J. POL. SCI. 97 (1976) (using regression analysis, with state supreme court opinions for 1966-1967 as the dependent variable).

71. A closer look at some of the "deviant cases," however, confirms the relationship between caseload control and page length. The Nevada Supreme Court (Type I) and the Oregon Supreme Court (Type II) wrote opinions that were considerably longer, on the average, than the mean for their respective groups, taking the whole 1940-1970 period, but that seems to result, at least in part, from their low caseloads during the first part of the period. In the 1945 1955 period, the Nevada Supreme Court averaged a mere 36 opinions a year, and the Oregon Supreme Court averaged 115 . The opinions of both courts in those years were extraordinarily long: Nevada averaged 9 pages, and Oregon 8.8. In 1960-1970, however, when the Nevada Supreme Court averaged a more substantial 131 opinions a year and the Oregon court surged to an average of 274, the average opinion length dropped to 4.6 pages for Nevada and 4.2 for Oregon, far shorter than the 16-state mean and lower than the average for their "types." Thus, their high average page length for the 1940-1970 period (6.8 pages) reflects the long opinions of the earlier, low-caseload period.

In many ways, these interstate differences are less striking than the constant inflation of opinions during the century. Only Tennessee now produces shorter opinions than it did in the early decades of the century.

On opinion length and its relationship to styles of judicial reasoning, see Goutal, Characteristics of Judicial Style in France, Britain, and the U.S.A., 24 AM. J. CoMP. L. 43, 56-71 (1976). 


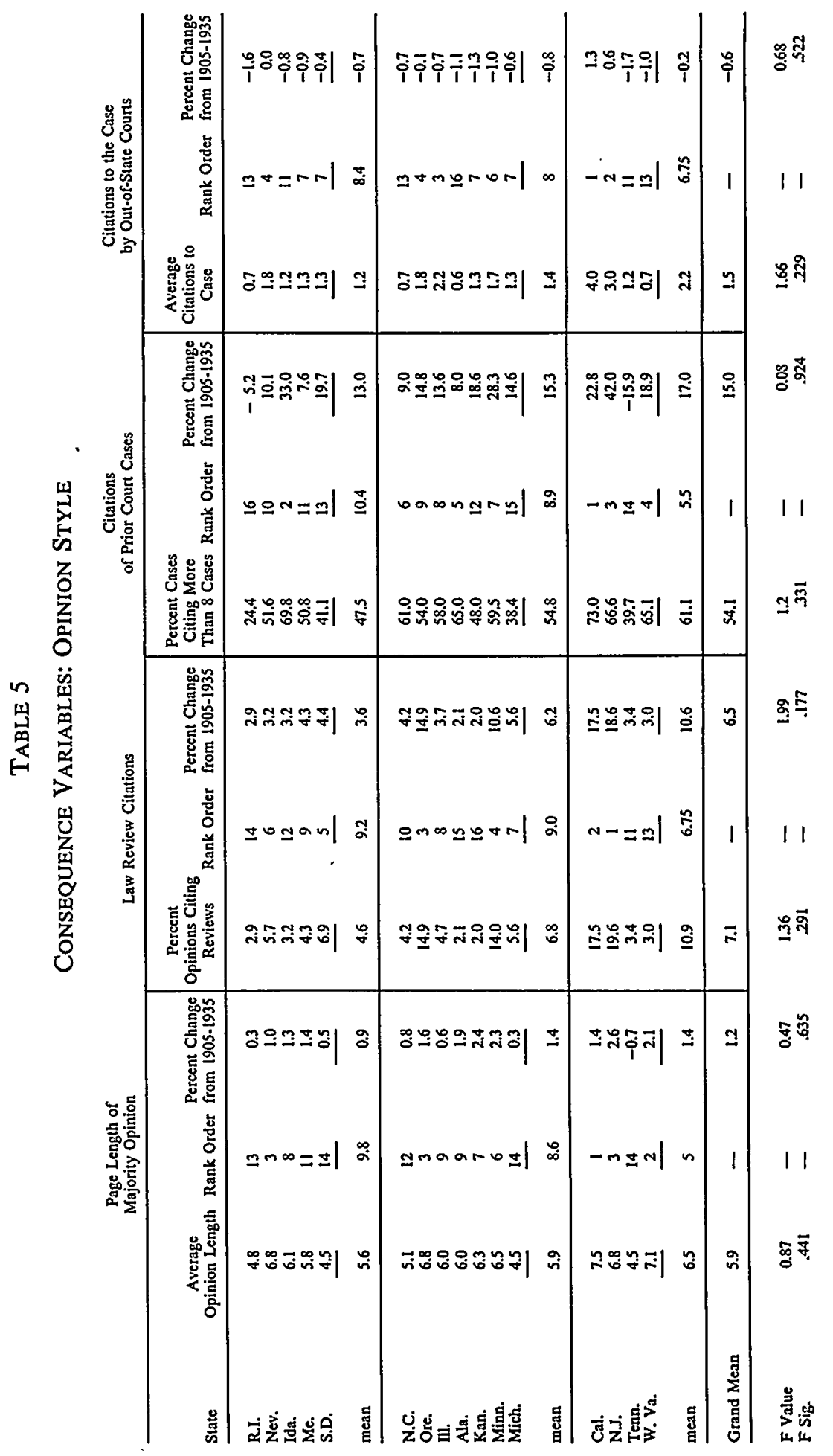


growing. ${ }^{72}$

Citations to case law were, of course, far more universal. Table 5 shows the tendency of supreme courts between 1940 and 1970 to cite earlier cases extensively. We drew an arbitrary line between cases that cited more than eight other cases and those that cited eight or fewer. The table shows the percentage of state supreme court cases which cited more than eight cases. California led here too- $73 \%$ of its opinions cited more than eight prior cases. Of the three other Type III states, New Jersey and West Virginia were also well above average; only Tennessee lagged. Type II courts averaged considerably fewer, and Type I courts fewer still, although Alabama and Idaho scored very high. There was some relationship, therefore, between habits of frequent citation and court type, but it was not strong. ${ }^{73}$

Finally, Table 5 indicates how many times, on the average, outof-state courts cited each state supreme court's published cases during the 1940-1970 period. It thus provides a rough measure of the relative influence of courts. Opinions by Type III courts were cited more often, but the differences are rather small. California and New Jersey led; the average California Supreme Court case was cited four times, the average New Jersey case three times. The only other state that averaged more than two citations per case was Illinois. Individual differences, however, seem stronger than differences by type of state. For example, other courts treated opinions from Tennessee and West Virginia with relative indifference, even though both were Type III courts.

72. Law reviews themselves vary tremendously in impact and prestige. See Maru, Measuring the Impact of Legal Periodicals, 1976 AM. B. Foundation RESEARCH J. 227.

Citations in California have been studied by John Henry Merryman, whose results are reported in Merryman, The Authority of Authority: What the California Supreme Court Cited in 1950, 6 STAN. L. Rev. 613 (1954), and in Merryman, Toward a Theory of Citations: An Empirical Siudy of the Citation Practice of the California Supreme Court in 1950, 1960, and 1970, $50 \mathrm{~S}$. CAL. L. REv. 381 (1977).

73. Looking closely at citations on a state-by-state basis, we found that the introduction of an intermediate appellate court and of supreme court case-selecting discretion consistently and substantially increased the number of case citations in supreme court opinions. In New Jersey, an extreme instance, the rate of citation in 1950-1970 was three times what it was in 1925-1945. In North Carolina, the 1970 citation rate was roughly double the 1960 and 1965 rate. Similar increases occurred in Kansas, Alabama and California when they instituted intermediate appellate courts in 1895, 1911 and 1904, respectively; the rate then declined in Kansas after the intermediate appellate courts were abolished in 1901.

The Tennessee Supreme Court's case citation rate increased after a limited intermediate appellate court was established in 1895, and then again in 1907 after the court was expanded, but it declined after jurisdictional revisions in the 1920s granted appeals from the intermediate appellate court as of right in a broad class of public-law cases and workmen's compensation matters.

The authors are grateful to Neil Coughlan for this state-by-state analysis. 


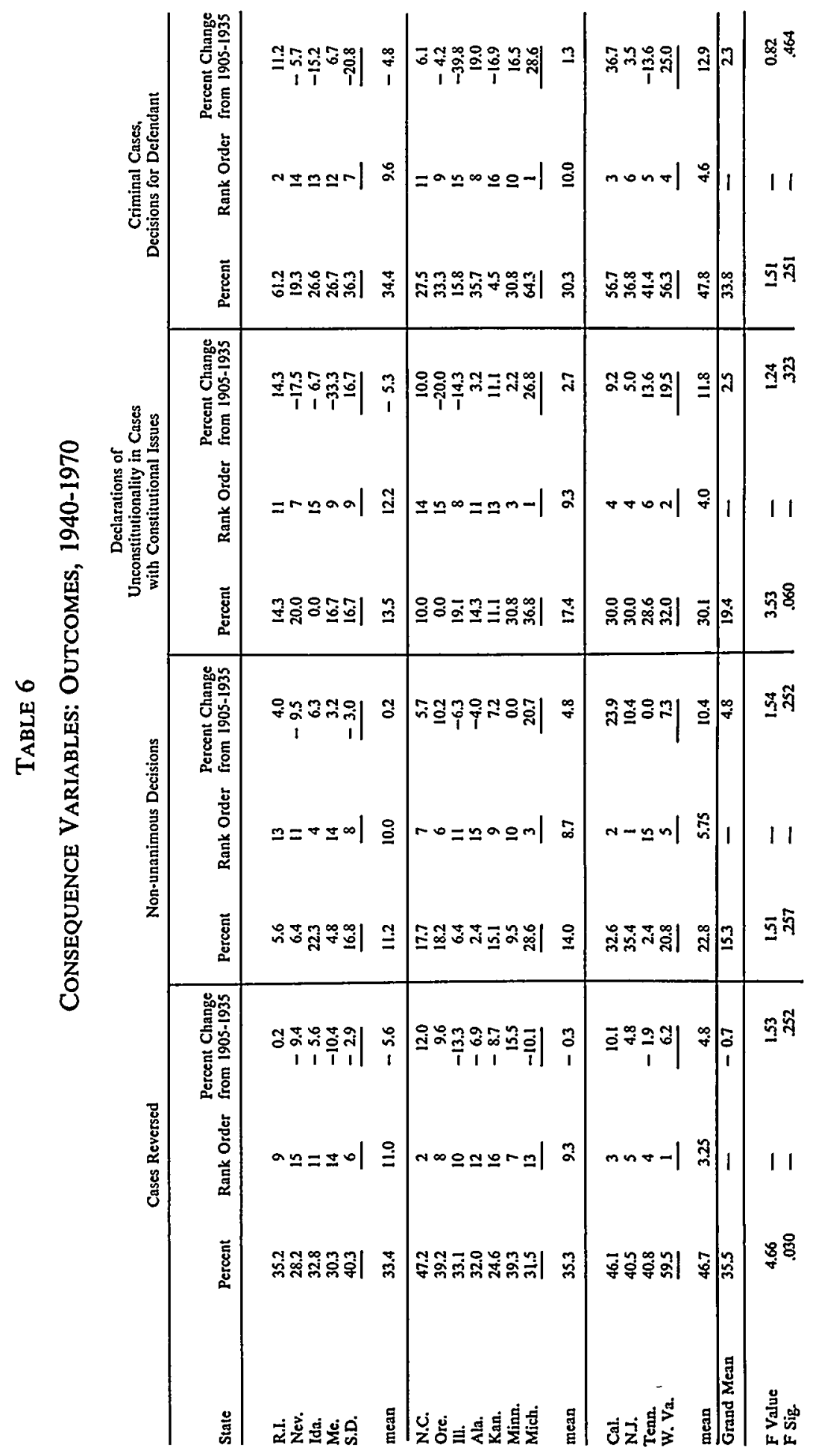




\section{Case Results}

Are the actual results of cases affected when supreme courts control their caseload? We looked at three measures of case results: the percentage of reversals by a supreme court; the percentage of nonunanimous supreme court decisions (the dissent rate); and the percentage of cases declaring laws, decisions, or practices unconstitutional, among cases that raise such issues. Table 6 displays the results of these three measures.

The three measures, especially the reversal rates, indicate that caseload control does make a difference. From the first third to the second third of the twentieth century, the reversal rate for Type I courts declined, while the reversal rate for Type III courts increased. From 1940 to 1970, Type I courts reversed only one-third of all the cases they reviewed. Type III courts reversed nearly half. Individual states ranged from the low reversal rate of $24.6 \%$ in Kansas to the high 59.5\% of West Virginia. Except for North Carolina, however, the reversal rate was higher in each of the Type III jurisdictions than in any of the courts that had less discretion to winnow out unmeritorious appeals. Of course, case-selecting discretion does not necessarily mean that supreme courts only take cases they intend to reverse. After all, most Type III courts reversed fewer than half of their cases. ${ }^{74}$

The dissent rates were not so uniform. Dissent has always been uncommon in Tennessee, ${ }^{75}$ but the other three Type III courts, West Virginia, California and New Jersey (all of which indeed had greater discretion than Tennessee), had higher dissent rates than the averages for Type I and Type II courts. This suggests either that these

74. For comparable data on reversal rates, see Canon \& Jaros, State Supreme Courts-Some Comparative Data, 42 ST. GovT. 260 (1969) (a study of a sample of decisions from all 50 state supreme courts, 1961-1967). To compute reversal rates, we had to decide which cases to include in the study and how to code decisions that reverse lower court decisions on some issues, but affirm on others. In addition to excluding cases decided with only very brief memorandum opinions, see note 4 supra and accompanying text, we coded as a reversal:

(1) any supreme court decision resulting in a substantial benefit to the appellant (compared to his position after the lower court decision), even if the decision produced, for example, a new trial rather than a final judgment in his favor,

(2) any supreme court victory for the plaintiff when petitions for habeas corpus or mandamus, formally original actions in the supreme court, in essence sought review of a lower court's decision (which very often was the case).

75. Some courts seem to discourage dissent consistently. More than $95 \%$ of the Alabama, Maine, Rhode Island, and Tennessee opinions were unanimous throughout the century of this study. 
courts chose controversial cases or that they had the time and inclination to emphasize the controversial issues in their cases. Yet here too, differences among states are more striking than differences among categories. Idaho, for example, had an unexpectedly high rate of dissent (22\%), although Nevada, a neighbor with a rapidly increasing caseload, was becoming increasingly unanimous. The Michigan Supreme Court, noted for its contentiousness, ${ }^{76}$ produced many dissents (28.6\%) despite its heavy caseload for most of the 1940-1970 period. In California and New Jersey, which perhaps represent the wave of the future, fully a third of the cases generated dissents. ${ }^{77}$

We noted that the Type III courts more often heard cases that raised constitutional issues. Table 6 shows that they were also more likely to declare a law or practice unconstitutional. Holding the number of constitutional issues constant, the small population states of Type I became on the whole less likely in the 1940-1970 period to declare an act or practice unconstitutional; on the average, they did so in only $13.5 \%$ of their cases. In Type III states, allegations of unconstitutionality were sustained about three times out of ten (30.1\%), compared to an average of $17.4 \%$ for the busier, low-discretion courts of Type II (although Michigan and Minnesota also scored high in this measure). ${ }^{78}$

Finally, the Type III courts were more likely, on the average, to decide in favor of defendants in criminal appeals, the most rapidly increasing and changing area of law during the last two decades of our research period. ${ }^{79}$ The Type III courts may or may not have

76. See Ulmer, The Political Party Variable in the Michigan Supreme Court, 11 J. Puy. L. 352 (1962).

77. After becoming a low-volume court with high discretion in 1967, the North Carolina Supreme Court began to write longer opinions, and its dissent and reversal rates went up. Groot, supra note 60, at 563-64. See also Canon \& Jaros, External Variables, Institutional Structure and Dissent on State Supreme Courts, 3 PoLITY 175 (1970); Jaros \& Canon, Dissent on State Supreme Courts: The Differential Significance of Characteristics of Judges, 15 MIDWEST J. POL. SCI. 332 (1971).

For data on dissent rates (as opposed to our figures on non-unanimous opinions, including both dissents and separate concurring opinions), see Canon \& Jaros, supra note 74, and C. Ducat \& V. Flango, Leadership in State Supreme Courts: Roles of the Chief Justice (1976) (Sage Professional Paper) (based on a survey of all decisions by 14 state supreme courts from 1951 to 1971). Our state-by-state data, when recalculated for dissent rates alone in the Canon \& Jaros and the $C$. Ducat \& V. Flango survey periods, closely resemble their findings.

78. Table 6 is based on the frequency of supreme court rulings of unconstitutionality. Courts without case-selecting discretion may be forced more often to hear weak or farfetched constitutional claims, and therefore may declare laws or acts unconstitutional less frequently, but in serious cases they may have just as great or greater an inclination to overturn statutes or practices as courts with more discretion.

79. Results for criminal appeals include habeas corpus petitions heard by state supreme courts. 
been more sympathetic to the underdog; the results may simply reflect their greater capacity to screen claims of defendants that were legally more tenuous. (The Michigan Supreme Court, otherwise a Type II court for most of the 1940-1970 period, did have discretion to accept or reject criminal appeals and had the strongest pro-defendant record.) ${ }^{80}$ Clearly, however, the courts with case-selecting discretion had a greater opportunity to use their time and energy to articulate new law at the frontiers of criminal procedure, rather than dealing with routine criminal matters routinely.

On balance, our rough indicators suggest that measurable changes in the subject and style of judicial opinions, and in results of decisions, coincide with increased discretion to select cases, with court reorganization, and with the changes in judges' sense of their own function that are likely to accompany reorganization. Perhaps the changes in subject, style, and result are not as great as some would expect, and obviously court organization is not the only factor influencing a supreme court's performance. But from 1940 to 1970, the high-discretion courts tended to move more rapidly into new areas of law and to accept more constitutional cases. Their higher rate of dissenting and separate concurring opinions suggests that their cases were more often controversial or that the judges were more likely to treat them as such. They reversed lower-court decisions more often, and they wrote longer opinions which cited cases and law reviews more often.

These rough measures do not necessarily mean that Type III courts write better opinions, of course. ${ }^{81}$ Nor can we say that the courts with low discretion do not invest substantial effort and debate in those cases they regard as important. ${ }^{82}$ At most we can say, rather

80. On the other hand, Rhode Island's supreme court, which had no formal case-selecting discretion, had the second highest rate of pro-defendant decisions in criminal cases. This and the widely varying results in the other low-discretion courts emphasize the obvious importance of other factors-presumably legal doctrine and judicial attitudes-in determining results, regardless of court structure.

81. We would agree in part with one analyst of state supreme court structure who said, "The only meaningful measure to which this third branch of government can be subjected is an analysis of its decisions. Trying to judge the court by other standards is a bit like attempting to describe the quality of a chocolate cake by giving the dimensions of its bakery box." Smith, supra note 58, at 97. We would add, however, that our goal here is not to describe the quality of the cake, but the changing organization and output of the bakery-which does affect its capacity to produce good cake.

82. In fact, if we examine only the most important opinions issued by lower-discretion state supreme courts (the $25 \%$ that received the most subsequent citations by other courts, 19401970), we find that they are much closer to the average Type III court opinion in length and in number of cases cited. But they are quite a bit shorter and have fewer citations than the most important Type III state supreme court opinions. Moreover, even the most important (most frequently cited) cases in Type I and Type II courts, 1940-1970, had a significantly lower rever- 
timidly, that the reduction of caseload in courts with high discretion may increase our chances of getting better judicial opinions. It would be bold to carry the matter much further. A century ago, the United States Supreme Court heard many quite ordinary cases-appeals from will contests or contract cases in the District of Columbia and diversity cases of all sorts-along with more dramatic fare. Those ordinary cases rarely reach the Supreme Court today, but can we confidently say that the Court's workmanship has therefore drastically improved? We think not. But we can say that today's Court cuts farther into the fabric of society and that its power and reach have grown tremendously. So, too, of state supreme courts with discretion, in the smaller realms of their states.

In sum, the findings set out in the tables, taken together, suggest that discretion to select cases affects the behavior of state supreme courts. More complex statistical analysis of our data, as set forth in the Appendix, ${ }^{83}$ confirms the results. The multivariate analysis refines the major findings and suggests the strengths and weaknesses of our results in more detail, but it yields no substantial differences in interpretation.

\section{ConClusion}

In the late nineteenth century, American state supreme courts were mainly reactive bodies. By and large, litigants chose the cases and determined the issues. The judicial system was democratic in theory; the states' highest courts were open to everyone, regardless of wealth or political influence, whether the claim represented a widespread issue, or was peculiar to a single suitor. As state populations grew, accessibility produced enormous caseloads for the high courts. Supreme courts in the larger states sometimes issued over 400 or

sal rate, dissent rate, and rate of declaration of unconstitutionality than even the average Type III court cases.

83. In brief, that analysis discloses that the "area of law" or "type of case" measures shown in Table 4 form a coherent multivariate "public-private law" dimension from 1905 to 1970. The opinion-style and citation measures shown in Table 5 form a coherent single dimension from 1940 to 1970; that is, states high on one measure in this period tend to be high on the others as well. The outcome measures in Table 6, however, do not seem to reflect a common underlying dimension. State supreme court caseload control is only weakly related to a concentration on public-law issues in the 1960-1970 period; that relationship is not statistically significant at the .05 level, perhaps because of the small number of states in the sample. Caseload control has a fairly strong relationship to opinion style and density of citations (a borderline significance at the .08 level) and to reversal rates (significant at the .002 level). Since there is also a positive relationship between opinion style and reversal rate, they can be combined into a single dimension whose overall relationship to caseload control is significant at the .02 level. However, the strength of the relationships may be either overstated or (more probably) understated due to the difficulty of accurately measuring "caseload control" with a three-group typology of states. 
even 500 opinions a year. Compared to courts with smaller caseloads, their opinions were shorter and (perhaps) more perfunctory. The courts were criticized for delays and backlogs, for the mechanical quality of their opinions, and for their inattention to a changing society. Some of these complaints were unfair or were unrelated to judicial structure, but they helped spur a movement for structural reform.

By 1970, all the large and most of the not-so-large states had achieved some measure of reform, though changes had generally occurred slowly and painfully. Political opposition and traditional notions of the judicial function impeded reform. Finally, most of the medium-sized and large states created intermediate appellate courts to absorb much of the supreme court caseload; these states also gave their courts discretion to choose the appeals they wanted to hear. The courts could therefore concentrate on appeals that they thought meritorious or that raised important issues of policy or principle. Their job was no longer defined primarily as one of correcting lowercourt errors. They had larger professional staffs and, in many instances, considerable power to issue rules of procedure.

These changes affected the daily work of the courts. Between 1940 and 1970, the supreme courts with high discretion wrote fewer opinions than the other courts. Their opinions tended to be longer and to cite more cases. They also reversed lower court decisions more often. Their opinions contained more dissents and concurrences. These courts tended to decide more constitutional issues; and they invalidated statutes or procedures more often, on the average, than the low-discretion courts. They spent somewhat less time with commercial and real estate cases (the traditional staples of state supreme court business), and more time on criminal- and public-law cases. And in criminal cases, they more frequently reversed the lower courts. Some of these differences were surprisingly slight, and not all high-discretion courts behaved alike. Nevertheless, our rough indicators point in the same direction: changes in court organization seemed to make some difference in the agendas, opinion styles, and decisions of the state supreme courts.

Intermediate appellate courts and case-selecting discretion do not, to be sure, solve the workload problem for state supreme courts. The number of cases decided with full opinions seems manageable, but supreme court judges and their clerks must somehow find time to screen the petitions for review that flood the courts. In California, for example, petitions to the supreme court for review of lower appellate court decisions climbed from 803 in the 1961-1962 term to 
2,417 in 1971-1972; total case filings, including original actions, were $3,238.84$ Some observers think that the job of screening petitions and the methods used to speed up that job have hurt the quality of the court's work. ${ }^{85}$ In a way, then, the largest states may have reached a fourth stage of high discretion, low caseload, but high workload. In those states, the court must devise more efficient case-selection techniques. ${ }^{86}$ The question is no longer whether this screening should be done, but how and by whom. By the judges themselves? By a professional staff? Or by some combination? And with what procedures?

Most states have accepted the idea that a supreme court should concentrate primarily on the most important cases, on articulating and elaborating principles of law. Some observers applaud this development and call it progress. Our society benefits, they say, when the states' highest courts are aware of issues, policies, and consequences and are responsive to changing circumstances and values. Others find the trend disturbing. The courts, they say, are illequipped to act as "roving commissions" in solving social problems." 87 Because there are inevitable limits on the information available to supreme courts, and because of the piecemeal, case-bycase manner in which they act, it is dangerous, the critics charge, to let courts seek out big issues and change the law in big steps. ${ }^{88}$ Thus, there are those who fear grave miscalculation and social disruption if a handful of judges, unrestrained by the ordinary electoral process, or the need to balance a budget, are encouraged to concentrate on important cases with incredible social impact.

The debate goes on, perhaps endlessly. Are judges capable of

84. Judiclal Council of California, Part II: ANnual Report of the Administrative Office of the California Courts 173 (1973). See Clark, American Supreme Court Caseloads: A Preliminary Inquiry, Law in the U.S.A. in the Bicentennial Era, 26 (Supp.) AM. J. Comp. L. 217, 218 (1978); Note, A Statistical Analysis of the Workload of the California Supreme Court, 65 CaLIF. L. REv. 531, 532 (1977).

85. See Johnson, Foreword: The Accidental Decision and How It Happens, 65 CALIF. L. Rev. 231 (1977). On the decline of collegial discussion, see Smith, The Appellate Decisional Conference, 28 ARK. L. REV. 425 (1975).

86. See generally P. Carrington, D. MEAdor, \& M. Rosenberg, Justice on APPEAL (1976); Meador, Appellate Case Management and Decisional Processes, 61 VA. L. REv. 255 (1975). See also Black, The National Court of Appeals: An Unwise Proposal, 83 YALE L.J. 883 (1974); J. Goldman, The Appellate Settlement Conference: An Effective Procedural Reform? (1977) (paper delivered at the American Political Science Association, annual meeting).

87. A. Bickel, The Supreme Court ANd the Idea of Progress 134 (1970).

88. See D. Horowitz, The Courts AND Social Policy (1977). See also Glazer, Towards an Imperial Judiciary?, THE PUB. INTEREST, Fall 1975, at 104, noting that even the "conservative" Burger Court, supposedly packed with "strict constructionists" by Richard Nixon, has continued to "make new law" quite boldly in several areas. 
intelligent policy-making and innovation? ${ }^{89}$ Should they take the initiative in problems of policy and justice, when legislatures, police departments, and bureaucracies are deadlocked or inert? No amount of data will resolve that question. Our study has revealed patterns of supreme court evolution toward smaller numbers of opinions and greater case-selecting discretion. State supreme courts can, and indeed are now designed to, concentrate on "key" cases. This has weakened some traditional institutional restraints on activism. For these, as well as other reasons, the courts are unlikely to turn back to a less activist role.

89. For a more affirmative view, see Chayes, The Role of the Judge in Public Law Litigation, 89 HARV. L. Rev. 1281 (1976). See also Carter, When Courts Should Make Policy: An Institutional Approach, in Public LAW AND PUblic Policy 141 (J. Gardiner ed. 1977). 


\section{Multivariate APPENDIX}

Do the consequence variables (area of law, opinion style, and case results) form common multivariate factors? If so, how are these factors related to state supreme court discretion? Does caseload-control affect all factors uniformly or some factors more than others? To answer these questions, we will factor-analyze the consequence variables and then examine mean differences on the resulting factor scores (the dependent variables) across the three state supreme court discretion groups (the independent variable).

Table A presents a two-factor solution for all consequence variables in the periods $1905-1935$ and 1940-1970. Al The major variables-areas of law, opinion style, and case results-tend to follow different reliability patterns. Law variables form a stable cluster from 1905 to 1970 . Some states emphasize business and tort issues. Other states emphasize criminal- and public-law issues. But the state rankings on these issues appear constant from 1905 to 1970. Opinion variables, on the other hand, coincide for 1940-1970, but not for 1905-1935. Measures of opinion style (page length of the majority opinion, judicial citations per page, and law review citations) and its reputation or use among other courts (Shephard's citations) are positively loaded for 1940-1970, but weakly loaded before 1940. Finally, outcome variables do not provide a single unified factor either within or across time periods. The dissent variable has a positive loading for both 1905-1935 and 1940-1970, but neither reversals nor declarations of unconstitutionality are strongly tied across time or to other outcome variables. Overall, these results suggest diverse relationships: law variables appear to tap a common public-private dimension in both time periods, opinion-style variables only seem to produce a single dimension in the last period and outcome variables probably do not produce a unitary dimension in either time period.

Since the consequence variables have different internal reliabilities over time, it is difficult (and not very meaningful) to examine factor score means for the entire period 1905-1970, but we can test these relations for a limited time period. We have chosen the period 1960 to 1970 because it is the first time period to break the general relation between population pressures and opinion caseloads. This period also shows interesting growth disparities between states with increasing and decreasing caseloads (a phenomenon obscured by the nationwide caseload decline between 1930 and 1945).

A1. Multiple factors, up to five with eigenvalues greater than 1.0, can be extracted from these variables. But a two-factor solution allows a concise and easily interpretable summary. The correlations in this factor analysis are based on the state percentages for each variable rather than the cases in the original sample. 
TABle A

SUMmary of TEMPoRAL Relations, 1905-1970

\begin{tabular}{|c|c|c|c|c|c|c|}
\hline & & $\begin{array}{l}\text { Unrot } \\
\text { Princ } \\
\text { Compo }\end{array}$ & $\begin{array}{l}\text { tated } \\
\text { cipal } \\
\text { onents }\end{array}$ & $\begin{array}{l}\text { Vari } \\
\text { Load }\end{array}$ & $\begin{array}{l}\max \\
\text { lings }\end{array}$ & \\
\hline Variables & & I & II & I & II & $\begin{array}{l}\text { Commun- } \\
\text { alities }\end{array}$ \\
\hline \multicolumn{7}{|l|}{ Area of Law } \\
\hline $\begin{array}{l}\text { Constitutional } \\
\text { Constitutional } \\
\text { Crime, Public } \\
\text { Crime, Public } \\
\text { Property, Business } \\
\text { Property, Business } \\
\text { Private Torts } \\
\text { Private Torts } \\
\end{array}$ & $\begin{array}{l}1905-1935 \\
1940-1970 \\
1905-1935 \\
1940-1970 \\
1905-1935 \\
1940-1970 \\
1905-1935 \\
1940-1970 \\
\end{array}$ & $\begin{array}{r}.554 \\
.947 \\
.815 \\
.901 \\
-.576 \\
-.672 \\
-.438 \\
-.733 \\
\end{array}$ & $\begin{array}{r}.021 \\
.153 \\
-.395 \\
-.249 \\
.497 \\
.223 \\
.084 \\
.346 \\
\end{array}$ & $\begin{array}{r}.524 \\
.861 \\
.895 \\
.935 \\
-.696 \\
-.708 \\
-.444 \\
-.802 \\
\end{array}$ & $\begin{array}{r}.181 \\
.422 \\
-.140 \\
.025 \\
.308 \\
.017 \\
-.047 \\
.118\end{array}$ & $\begin{array}{l}.308 \\
.920 \\
.821 \\
.874 \\
.579 \\
.501 \\
.199 \\
.658\end{array}$ \\
\hline \multicolumn{7}{|l|}{ Style and Citations } \\
\hline $\begin{array}{l}\text { Page Length } \\
\text { Page Length } \\
\text { Cites Per Page } \\
\text { Cites Per Page } \\
\text { Shephard's Cites } \\
\text { Shephard's Cites } \\
\text { Law Review Cites } \\
\text { Law Review Cites }\end{array}$ & $\begin{array}{l}1905-1935 \\
1940-1970 \\
1905-1935 \\
1940-1970 \\
1905-1935 \\
1940-1970 \\
1905-1935 \\
1940-1970\end{array}$ & $\begin{array}{r}.721 \\
.242 \\
-.100 \\
.316 \\
.536 \\
.626 \\
.064 \\
.207\end{array}$ & $\begin{array}{r}.085 \\
.577 \\
-.349 \\
.516 \\
-.049 \\
.661 \\
.180 \\
.850\end{array}$ & $\begin{array}{r}.665 \\
.064 \\
.006 \\
.152 \\
.527 \\
.406 \\
.008 \\
-.049\end{array}$ & $\begin{array}{r}.291 \\
.623 \\
-.363 \\
.586 \\
.109 \\
.815 \\
.190 \\
.874\end{array}$ & $\begin{array}{l}.528 \\
.392 \\
.132 \\
.366 \\
.290 \\
.829 \\
.036 \\
.766\end{array}$ \\
\hline \multicolumn{7}{|l|}{ Outcomes } \\
\hline $\begin{array}{l}\text { Reversals } \\
\text { Reversals } \\
\text { Dissent } \\
\text { Dissent } \\
\text { Unconstitutional } \\
\text { Unconstitutional }\end{array}$ & $\begin{array}{l}1905-1935 \\
1940-1970= \\
1905-1935 \\
1940-1970 \\
1905-1935 \\
1940-1970\end{array}$ & $\begin{array}{l}.334 \\
.187 \\
.089 \\
.076 \\
.399 \\
.399\end{array}$ & $\begin{array}{r}-.297 \\
.263 \\
.545 \\
.752 \\
.115 \\
.104\end{array}$ & $\begin{array}{r}.406 \\
.103 \\
-.074 \\
-.147 \\
.348 \\
.351\end{array}$ & $\begin{array}{r}-.187 \\
.306 \\
.547 \\
.742 \\
.226 \\
.216\end{array}$ & $\begin{array}{l}.200 \\
.104 \\
.305 \\
.572 \\
.172 \\
.170\end{array}$ \\
\hline $\begin{array}{l}\text { Eigenvalues } \\
\% \text { Variation }\end{array}$ & \multicolumn{6}{|c|}{$6.466 \quad 4.080$} \\
\hline
\end{tabular}

Table B reports factor loadings for the consequence variables, 1960-1970. The results follow the 1940 to 1970 patterns in Table A. Law areas form a single public-private dimension. Page length and the citation variables form a single depth and intensity of research dimension. No evidence exists, however, of a single outcome dimension (reversals load .48 on the opinion research factor and dissents load .81 on the residual third factor, but no combination of outcome variables has a loading of .40 on a common factor). Since reversals have a borderline .48 loading on the opinion research factor, we will compare the opinion factor, with and without reversals, in the factor score analysis. 
TABLE B

FACtor LoAdings For Consequence Variables, 1960-1970

\begin{tabular}{|c|c|c|c|c|c|c|c|}
\hline & \multicolumn{3}{|c|}{$\begin{array}{l}\text { Unrotated Principal* } \\
\text { Components Loading }\end{array}$} & \multicolumn{3}{|c|}{$\begin{array}{l}\text { Varimax Rotated } \\
\text { Loadings }\end{array}$} & \multirow[b]{2}{*}{$\begin{array}{c}\text { Commun- } \\
\text { alities }\end{array}$} \\
\hline Variables & I & II & III & I & II & III & \\
\hline \multicolumn{8}{|l|}{ Area of Law } \\
\hline $\begin{array}{l}\text { Constitutional } \\
\text { Crime, Public } \\
\text { Property, Business } \\
\text { Private, Torts }\end{array}$ & $\begin{array}{r}.814 \\
.515 \\
-.522 \\
-.461\end{array}$ & $\begin{array}{r}-.264 \\
-.706 \\
.463 \\
.782\end{array}$ & $\begin{array}{r}-.162 \\
.103 \\
.498 \\
-.383\end{array}$ & $\begin{array}{r}.419 \\
.037 \\
.055 \\
-.209\end{array}$ & $\begin{array}{r}.747 \\
.864 \\
-.804 \\
-.747\end{array}$ & $\begin{array}{r}.195 \\
-.160 \\
-.291 \\
.608\end{array}$ & $\begin{array}{l}.758 \\
.774 \\
.734 \\
.971\end{array}$ \\
\hline \multicolumn{8}{|l|}{ Style and Citations } \\
\hline $\begin{array}{l}\text { Page Length } \\
\text { Cites Per Page } \\
\text { Shephard's Cites } \\
\text { Law Review Cites }\end{array}$ & $\begin{array}{l}.622 \\
.560 \\
.849 \\
.597\end{array}$ & $\begin{array}{l}.141 \\
.342 \\
.243 \\
.459\end{array}$ & $\begin{array}{l}.430 \\
.282 \\
.025 \\
.127\end{array}$ & $\begin{array}{l}.744 \\
.708 \\
.755 \\
.708\end{array}$ & $\begin{array}{r}.151 \\
.008 \\
.331 \\
-.011\end{array}$ & $\begin{array}{r}-.121 \\
.090 \\
.319 \\
.287\end{array}$ & $\begin{array}{l}.591 \\
.509 \\
.781 \\
.584\end{array}$ \\
\hline \multicolumn{8}{|l|}{ Outcomes } \\
\hline $\begin{array}{l}\text { Reversals } \\
\text { Dissent } \\
\text { Unconstitutional }\end{array}$ & $\begin{array}{l}.441 \\
.488 \\
.363\end{array}$ & $\begin{array}{l}.246 \\
.575 \\
.089\end{array}$ & $\begin{array}{r}.079 \\
-.473 \\
-.162\end{array}$ & $\begin{array}{l}.476 \\
.372 \\
.229\end{array}$ & $\begin{array}{l}.065 \\
.011 \\
.203\end{array}$ & $\begin{array}{l}.175 \\
.809 \\
.268\end{array}$ & $\begin{array}{l}.261 \\
.793 \\
.166\end{array}$ \\
\hline $\begin{array}{l}\text { Eigenvalues } \\
\text { \%Variation }\end{array}$ & $\begin{array}{l}4.092 \\
37.2\end{array}$ & $\begin{array}{l}2.431 \\
22.1\end{array}$ & $\begin{array}{l}1.294 \\
11.8\end{array}$ & & & & \\
\hline
\end{tabular}

* $\mathrm{R}^{2}$ initial diagonal elements with iteration (SPSS method PA2) and minimum eigenvalues = 1.0.

Table C presents the factor score means, 1960-1970, across the three-state supreme court discretion groups. The factor score means tell approximately the same story as the percentage differences in Tables 4 to 6 . While state supreme court discretion has a weak and insignificant relation to the public-private law dimension (a significance level of .17), it has a borderline relation to the opinion factor (a significance level of .08) and a fairly strong relation to the reversal variable (a significance level of .002). If the opinion factor and the reversal variable are combined into a single dimension (as suggested by Factor I in Table B), the overall relation to state supreme court discretion remains statistically significant at the .02 level.

Based on these results, it seems likely that a case-screening capacity affects (a) a court's tendency to reverse lower-court decisions; and (b) the quantity, if not the quality, of its investments in opinion research and drafting. But a state supreme court's case-screening capacity does not unambiguously affect the relative distribution of public- and private-law issues before the court.

A2. For a discussion of reliability estimates using highest loading factor sales, see Armor, Theta Reliability and Factor Scaling, in SociologicAl METHODOLOGY, 1973-1974, at 33-49 (H. Costner ed.). 


\begin{tabular}{|c|c|c|c|c|c|c|c|}
\hline & & 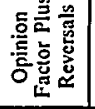 & $\vec{i}$ & $\stackrel{9}{i}$ & 2 & $:$ & مै \\
\hline & & 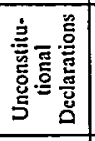 & $\hat{i}_{i}^{n}$ & $\overrightarrow{0}$ & a & $:$ & $8 \stackrel{5}{7}$ \\
\hline$\frac{2}{9}$ & | & 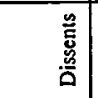 & §̊̊ & $\vec{i}$ & $\because 8$ & $\therefore$ & पे \\
\hline 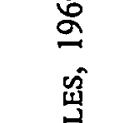 & & 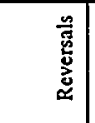 & î̀ & : & $m$ & 8 & $\stackrel{\circ}{\stackrel{8}{8}}$ \\
\hline$\underset{3}{x}$ & & |c| & $\stackrel{0}{i}$ & $\hat{i}$ & $\stackrel{\infty}{\circ}$ & 8 & 요 \\
\hline $\begin{array}{l}\text { 嵌 } \\
\text { z } \\
\text { 总 }\end{array}$ & . & 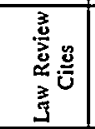 & 苂 & $\therefore$ & $:$ & 8 & $=\stackrel{\odot}{\%}$ \\
\hline 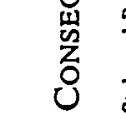 & . & 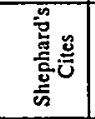 & $\hat{i}_{i}^{n}$ & $\tilde{i}$ & 8 & 8 & $\overline{\mathrm{j}}$ \\
\hline 竞 & 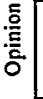 & 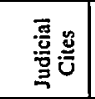 & : & $\vec{i}$ & $\hat{0}$ & $\because$ & \ః \\
\hline 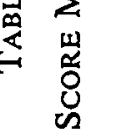 & & 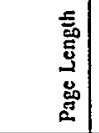 & 苂 & $\tilde{i}$ & $\stackrel{\infty}{\circ}$ & 8 & ส \\
\hline $\begin{array}{c}N \\
\text { 卢 } \\
\text { 总 }\end{array}$ & & 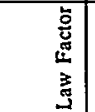 & : & $\stackrel{0}{i}$ & $\pi$ & 8 & $\underset{\mathrm{j}}{ } \cong$ \\
\hline ¿ & 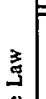 & 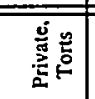 & $\tilde{i}$ & 3 & : & $:$ & $\overline{\bar{j}}$ \\
\hline$\underset{\xi}{z_{2}}$ & 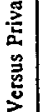 & 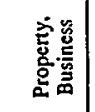 & $\bar{i}$ & $\stackrel{+}{0}$ & ì & 8 & 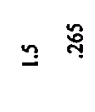 \\
\hline 岂 & 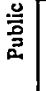 & 昜昜言 & 3 & $\hat{i}$ & 3 & 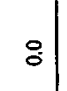 & $\therefore$ \\
\hline 点 & & 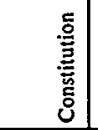 & ĩ & $\hat{i}$ & $\stackrel{\infty}{\infty}$ & $\therefore$ & $\vec{\sigma}$ \\
\hline & & 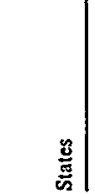 & 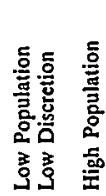 & 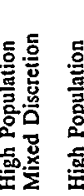 & | & 苞 & 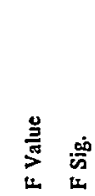 \\
\hline
\end{tabular}

